\title{
PUBLIC MEETINGS ON NUCLEAR WASTE MANAGEMENT : THEIR FUNCTION AND ORGANIZATION
}

EUGENE G. DUVERNOY

ALFRED A. MARCUS

TOM OVERCAST

A. HANK SCHILLING

MAY 1981

Prepared for the Waste Management Systems Studies Program of the Pacific Northwest Laboratory of the U.S. Department of Energy under contract DE-AC06-76RLO-1830

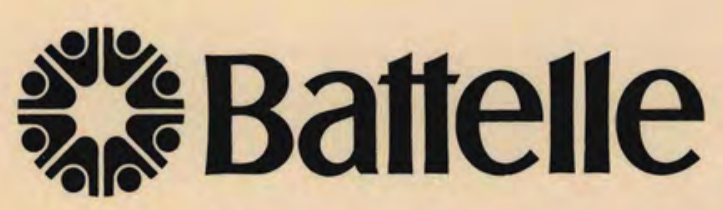

Human Affairs Research Centers

4000 N.E. 41st Street $\bullet$ Seattle, Washington 98105 


\section{Legal Notice}

This report was prepared by Battelle as an account of sponsored research activities. Neither Sponsor nor Battelle nor any person acting on behalf of either: (a) Makes any warranty or representation, express or implied, with respect to the accuracy, completeness, or usefulness of the information contained in this report or that the use of any information, apparatus, process, or composition disclosed in this report may not infringe privately owned rights; or (b) Assumes any liabilities with respect to the use of, or for damages resulting from the use of, any information, apparatus, process, or composition disclosed in this report. 
PNL -4062

BHARC $-311 / 81 / 031$

$\mathrm{UC}-70$

Public Meetings on

Nuclear Waste Management:

Their Function and Organization

By

Eugene G. Duvernoy

Alfred A. Marcus

Tom Overcast

A. Hank Schilling

Prepared for the Waste Management Systems Studies Program

of the Pacific Northwest Laboratory

of the U.S. Department of Energy

under contract DE-AC06-76RLO-1830

May, 1982

Battelle Human Affairs Research Centers 4000 N.E. 4lst street Seattle, washington 98105 


\section{EXECUTIVE SUMMARY}

This report focuses on public meetings as a vehicle for public participation in nuclear waste management. The nature of public meetings is reviewed and the functions served by meetings highlighted. The range of participants and their concerns are addressed, including a review of the participants from past nuclear waste management meetings. A sound understanding of the expected participants allows DOE to tailor elements of the meeting, such as notification, format, and agenda to accommodate the attendees. Finally, the report discusses the organization of public meetings on nuclear waste management in order to enhance the DOE's functions for such meetings. Possible structures are suggested for a variety of elements that are relevant prior to, during and after the public meeting. These suggestions are intended to supplement the DOE Public Participation Manual. 
Chapter 1: Introduction................ 1

Chapter 2: The Nature of the Public Meeting. . . . . 8

Chapter 3: Public Meetings: Participants and their Concerns. . . . . . . . 17

Chapter 4: Organization and Management of Public Meetings on Nuclear Waste ......... 44

Appendix 1: Guidelines for Determination of Need for Public Meetings. . . . . . . . 76

Appendix 2: Organization, Purpose, and Format of Past Nuclear Waste Meetings . . . . . . 82

\section{LIST OF TABLES}

Table 1 Public Meetings for Nuclear Waste Management. . . . . . . . 18

Table 2 Convenor and Participants Concerns. . . . . . . . . . . 24

Table 3 Participation at Nuclear Waste Meetings. ........... 26

Table 4 Dominant Factions at Past Public Meetings ........... 30

Table 5 Concerns of IRG Participants.........33

Table 6 Concerns of EIS Participants. . . . . . 35

Table 7 Ratio Between Nontechnical and Technical Issues Among Participants at GEIS Meetings. . . . . . . . . 36

Table 8 Meeting Elements Relevant to DOE Functions ............. 47 
CHAPTER 1

Introduction

This report will focus on public meetings as a vehicle for public participation in Nuclear Waste Management. The nature of public meetings is discussed in Chapter 2. Chapter 3 reviews the characteristics and concerns of participants and chapter 4 discusses the administration of public meetings and is included to supplement the Department of Energy Citizen Participation Manual, DOE 1210.1.

Governmental agencies are often hard pressed to determine the most effective means for responding to the need for public involvement in the decision-making process. The failure to effectively involve the public may lead to seriously misguided policies and projects, as well as a violation of a legislative mandate, and may result in delays if the decison process or the implementation of the decision itself is interrupted by judicial or administrative intervention.

It is important at the outset to distinguish between public meetings, the focus of this report, and public hearings. For purposes of public involvement and participation, there are important structural and functional differences between meetings and hearings that merit discussion.

Public hearings are formal and highly structured quasi-judicial proceedings for eliciting the responses of interested parties to a proposed governmental action. The 
record of the hearing frequently provides the sole basis for the subsequent governmental action. Hearings also are generally characterized by such elements as the formal presentation of testimony from groups and individuals with little opportunity for interaction between participants and government officials, except for cross examination, and a formalized set of rules of procedure which govern the conduct of the hearing.

Public meetings, on the other hand, are informally structured mechanisms to facilitate public participation in a pending governmental action. The procedures to be eimployed are not dictated by law or agency regulation. Rather, a public meeting can be specifically structured to accomplish its designated functions. In contrast to public hearings, a public meeting may greatly influence an agency's decision on a proposed action, but rarely does it provide the sole basis for the decision. Public meetings generally have many of the advantages of the public hearing without the rigidity and formality of hearing procedures and the costs associated with establishing.an official record.

Because of the lack of existing data, the information in this report will be exclusively qualitative, based on the direct experience of HARC staff, acquired by either active involvement or observation of the meeting process, and on secondary sources. General principles will be developed to allow more effective structuring and functioning of public meetings: These tasks were pursued in order to provide the foundation for 
improving the use of the public meeting as a mechanism for meeting the needs of both the government and the public.

Two important caveats need to be emphasized at the outset. First, citizen involvement and participation, whether through public meetings or any of the myriad of other public participation techniques, will not make the decision for the agency. Public involvement certainly is a necessary but not sufficient condition for public acceptance of governmental actions. The competing interests and deeply held commitments illuminated by public involvement may often make decision-making/consensus-building more difficult, especially on issues having long-term national import. The final decision which results from the process, however, should be more representative of the public's concern.

Second, even in the absence of a formal procedure for public participation, such as public meetings, governmental decisions are not made independently of some measure of the public will. For example, an agency's specific mission and funding level are established by pluralistic processes by legislatures which take into account the interests of established groups and, purportedly, the general public. If the agency's goals are well-defined and public attitudes stable, this level of public involvement through legislative representation may be optimal. It may not be successful, however, if a public consensus has not emierged or if large. numbers of people are polarized over a controversial issue. 
Though not explicitly considered, public sentiment or attitudes may also affect an agency's policies through the roles adopted by the decision-maker. For example, as a functioning member of the general society, the decision-maker is aware of public opinion and presumably has internalized the norms and values of society. The particular background, experiences and personality of the decision maker may combine to form pre-existing preferences which contribute to broad policy directions. The decision-maker may also be subjected to informal lobbying from friends, family, co-workers, and others. A Decision-maker's own opinion is not necessarily a useful indicator of public opinion in general, nor a very good predictor of his or her actual behavior (White, 1966). Nonetheless, it is indicative of some feeling for the public opinion and should be taken into account.

\section{Focus}

The analysis in this report is mainly concerned with citizen involvement at three levels: (1) in the formation and execution of a policy, (2) in specific projects implemented within a particular policy, and (3) in the resolution of particular issues that arise within a specific project. The main reason for this focus is that public participation at these levels is more often managed by a governmental agency rather than the judicial or legislative branches of government, and participation at this level is usually what is meant by the phrase 'public participation'. 
It should also be understood that the demand for public participation does not arise in regard to all issues which affect the public. Under normal circumstances, in fact, there is very little demand for citizen involvement. One commentator (Reidel, 1972) has noted that there is little demand for public input into the process of fixing licensing standards for psychologists, surgeons, or plumbers, even though these matters are more Iikely to directly touch the lives of nearly all individuals at one time or another. Reidel notes that a general concern for effective public participation occurs:

-. . in the context of real or imagined failure of government to respond appropriately to the more competitive needs and demands of citizens, some of whom feel that the governmental response would have been more satisfactory had their values been given and assured their hearing. In short, the real issue connotes criticism of the existing system of representation.

Another important factor, however, that tends to increase the demand for public participation and involvement is the number of different groups which have competing or conflicting interests. These same issues have been dealt with in terms of trust. As long as the public trusts the decision-maker to act in its best interest, the public does not feel a need to participate. As the degree of trust erodes, however, the perceived need for public involvement increases (Gamson, 1968). The public trusts those who set standards for psychologists and plumbers (although to a much lesser degree today than in the past) and, thus, does not feel the need to have an active participatory role. 
In decisions relating to nuclear waste management, the factor that has most reduced the level of public trust and led to an increased public and legislative demand for greater citizen involvement is the diversity of potential and actual conflicts of interest between the publics which may be affected by the pending decisions. It is likely that any decision will leave a number of groups or individuals with the impression that the governemnt agency did not take into account, of or respond to, their needs. Moreover, the increase over the last decade in public awareness of the problems associated with energy production and environmental protection has led to the establishment of a number of interests groups representing! a variety of perspectives, which wish to reexamine the basic policies and practices associated with nuclear waste management. Finally, it is important to remember that the public meeting is just one of many different elements in the public participation process - a process which, in its entirety, may have many different objectives. As a result, regardless of how carefully a government agency structures and conducts a pưblic meeting, the meeting itself may not always appear to make a significant contribution to the objectives of the agency. While a successful public participation program can require the sensitive execution of a series of elements, the failure of one of the elements can act as a glaring focus for criticism of the proposed governmental action and can discredit the entire effort. Consequently, if porly structured or conducted, a 
public meeting has the pgtential to harm the entire public participation program. Accordingly, this report will focus on aspects of the public meeting which have the potential to damage as well as benefit the agency's participation and involvement efforts. 


\section{The Nature of the Public Meeting}

It seems inevitable that, whenever there is public or legislative demand for citizen involvement in a decision-making process, the most frequent response of government agencies is to hold a public meeting. Such meetings take place at all levels of government--federal; state, and local--and have in the past been one of the most important means of communication between the public and government.

At the same time, however, the public meeting as an institution or process has been seriously neglected by social scientists. There ampears to be almost no literature on even the most basic descriptive aspects of the meeting process, i.e., the topical distribution of meetings, who attends meetings, who participates, the style or format of participation, and the impact of participation. The paucity of information is in striking contrast to the voluminous literature on other citizen participation mechanisms such as voting. It is also in sharpccontrast to the attention paid to formal administrative hearings by social scientists and legal scholars. For example, Wald (1978) has commented on the relationship of the formal administrative hearing to the type of testimony to be presented, and has suggested changes in the hearing structure to accomodate the peculiar nature of economic theory and data that form the core of information presented at such hearings. 
In order to effectively organize and conduct a pgilic meeting, its nature must first be understood. For instance, a public meeting to inform the public of a new regional waste program should be conducted in a manner different from a pablic meeting to solicit input on passible solutions to a leak from a nuclear waste interim storage tank with highly localized impact. The nature of a public meeting can generally be characterized by reference to four elements:

1. subject matter of the public meeting. The express subject matter to be discussed at a public meeting:is an important element in characterizing its nature. The subject matter of such meetings can range froin issues in high-level nuclear waste to uranium mill tailings.

2. scale of the proposed governmental action. The scope of the proposed governmental action could consist of one of the following four levels of activity:

a. ratification of a propased waste management plan that addresses several distinct subject matter areas, such as a federal ptan for overall waste management;

b. the development of generic policy for a single subject matter area; c. the adoption of a specific program to implement a policy; and 
d. the approvaI of a particular project within a program.

3. authority for the pubIic meeting. The authority for the public meeting is a third element that may define its natare. The authority can be a legislative mandate which has been enhanced by case Iaw, a requirement within the DOE administrative regulations, an explicit recommendation from a DOE policy document, or merely a decision by DOE project or poIicy personnel based on general DOE public participation guidelines. This element is further discussed in Appendix 1, Guidelines for Determining the Need For a Public Meeting.

4. objective of the DOE. The final element in characterizing the nature of a ppblic meeting is the objective of the DOE personnel responsible for organizing the meeting.

Functions of the Public Meeting

Generally, public meetings--open meetings between governmental agency personnel and members of the public--have been viewed as performing four distinct functions. In any given meeting, the functions may overlap depending upon the issue under discussion and the individuals present. Thus a single meeting may serve many different functions for different participants. It should, however, be possible by carefully analyzing transactions and interactions to identify a single dominant function served at any meeting. 
(1) Obtaining information. Convenors, such as DOE, may see the public meeting as a vehicle to obtain information from the public. Under such conditions, what transpires at the meeting may, indeed, have a significant impact on governmental action. Often regarded as the ideal function of a public meeting; obtaining information, apparently is not an accurate description of how most meetings function. The risks of aiming to obtain information and failing may be loss of credibility and dissatisfaction on the part of both convenors and participants.

(2) Providing Information. Providing information is likely to be the dominant concern when citizens are brought together for the purpose of informing them about the nature of a governmental action or decision. Informational pjolic meetings usually involve a presentation describing the government action and extolling the benefits of the policy or proposed activities; and an opportunity for individuals to ask questions. In such meetings decision-makers are simply presenting their own point of view and often explicitly have no plans and make no provisions to react to public opinion or concern.

(3) Legitimation. A public meeting can be said to enforce the ligitimacy of a pending agency action when the meeting is held in compliance with a legal or regulatory requirement. An open decision process which recognizes the right of the pablic to comment on a proposed action and attempts in good faith, to 
satisfy this right enhances the Iegitimacy of the eventual governmental action. Moreover, individuals and groups given formal opportunity to provide input are preemptyed from later arguing they had no opportunity to be heard.

(4) Public acceptance. The need to obtain public acceptance may be the most important concern of the meeting's convenors. Without acceptance, obstruction to the propased governmental action is likely from grous and individuals concerned with the proposal. People are more likely to trust the results of open and objective decision processes which acknowledge and respond to criticisms than they are those which emerge from closed discussions among government experts and officials. The meeting may be viewed as a method of obtaining the support needed to carry out the policy.

\section{Problems of the Public Meeting Process}

The public participation literature is replete with examples illustrating specific problems in the citizen involvement process; little mention is made, however, of problems unique to public meetings. In this section we will attempt to delineate some generic categories of problems that are applicable to public meetings in a manner different from other methods of public participation.

Lack of representativeness. One of the more serious problems with public meetings is that the views presented there 
are suspected to be unrepresentative of the views of the range of individuals and groups likely to be affected by governmental action. For instance, white (1973) argues that public meetings are very likely to reflect only the already known views of identified interest groups. Similarly, in analyzing a public meeting on water quality standards, Fox and wible (1973) note that:

- - waste dischargers had a much more active voice in the process by which the standards were established - . than any other nongovernmental group.

Thus, to the degree that interested individuals or groups are a part of the established clientele of a particular governmental agency, the public meeting will not effectively shed new light on the decision-making process, and will be seen primarily as ritualistic in nature.

There are a number of sociological and psychological factors, primarily involving knowledge and motivation, that affect the public meeting process and contribute to the lack of representativeness of the views expressed at the meeting. Simply stated, the individual most likely to attend a public meeting is the one who:

1. personally believes that the issue will have an important impact. Representatives of interest groups are likely to be more knowledgeable about the issues and accurately believe that the governmental agency will be more responsive to their input than the ordinary citizen. Private citizens are likely to be knowledgeable about their own feelings about the issues, but are of ten uninformed about technical details and other implications of the decision alternatives. Additionally, it is not altogether unreasonable for private citizens to feel that their input will be of little concern to the governmental agency; 
2. is able to free him or herself from competing demands during the time of the hearing. Competing demands may also have a very significant effect on the representativeness of participants and may be a fundamental flaw in the fairness of the public meeting process. For example, in the water use meeting described by Fox and Wible (1973), outdoor recreational interests may have been underrepresented because the meeting was held during the local deer hunting season. It is also informative that many of the participants at the meeting were there in work-related capacities. Because members of the general public have to work during weekdays, meetings held during those times severely limit their ability to participate. The industrialist, while on the job, attends a public meeting to protect his or her interests. The environmentalist or recreationalist is also at work, but his or her work-related activities do not include attendance at a public meeting to protect nonwork-related interests. Fox and wible report that between June 18, 1973, and June 14, 1974, the Department of Natural Resources of the State of Wisconsin held 170 formal public meetings on a wide range of topics. Of these 170, all but two were held between $8: 00 \mathrm{a} . \mathrm{m}$. and 5:00 p.m. on weekdays;

3. views him or herself in a responsible role as a citizen;

4. is knowledgeable, to a greater or lesser extent, about the issues to be discussed; and

5. believes that his or her presence and input will have an impact on the decision-making process.

Members of the general public are much less likely to be aware of published notices concerning public meetings than are established interest groups who are closely tied to the issues being considered by the governmental agency and continually scrutinize the various sources for such ratifications. In addition, while the interest group normally has a clear focus on issues which affect its members, the ordinary citizen may have many other concerns that take precedence over issues in nuclear waste management. 
These factors not only limit attendance at public meetings, but it can be hypothesized that they also function to limit participation among those who do attend. Limited observations suggest that most individuals who do attend public meetings do not actively participate. Under normal circumstances, most people tend to communicate with each other face-to-face, either individually or in small groups. The majority of private citizens are probably very reluctant to stand up in front of an audience and deliver a monologue to a panel of governmental agency representatives. It is likely that many individuals who otherwise have sufficient motivation to attend a public meeting would be more willing to actively participate if the meeting environment was less alien and intimidating.

Predictability and foreknowledge. Another unavoidable problem with the public meeting as a means of citizen involvement is that it occurs before the proposed plan or policy is implemented. Thus participants are asked to comment on hypothetical future events. Do they favor the construction of this facility? How would they like to see it built? what should be done to protect the environment? How much income will accrue to the community as a result? Participants are asked to tell governmental agencies what they would or would not like in the future without having any experience with that future (Loye, 1978). 


\section{Conclusion}

The public meeting may not be a perfect vehicle for public participation. However, the functions it can be organized to provide can be indispensible to the ultimate success of a proposed agency action. If these functions are to be attained, the expected participants must be thoroughly understood and the meeting itself skillfully structured. 
PUBLIC MEETINGS: PARTICIPANTS AND THEIR CONCERNS

The purpose of this chapter is to present an analysis of participants at nuclear waste meetings and to discuss their concerns. An understanding of the participants expected at public meetings is useful. The convenors can then tailor elements of the meeting, such as notification, format, and agenda, to accommodate expected attendees. Panel members, moderator, and other participating officials can better prepare to respond to possible comments. In this chapter, published reports of past meetings (Table I) are reviewed (also see Appendix 2) and arguments for and against greater participation are examined.

\section{Participants}

Useful information concerning participants frequently can be obtained by examining the list of pre-registered participants--especially where organizational affiliation is identified--and from reviewing the public participation experience available within DOE. While it is rarely possible to acquire sufficient information to precisely define the character of the expected participants, it is still useful to prepare for a public meeting by knowing who is going to attend.

Social scientists (Schattschneider, 1960; Verba and Nie, 1972) have long noted that the views presented at public meetings are likely to be unrepresentative of the views of the 
TABLE 1: PUBLIC MEETINGS fOR NUCLEAR WASTE MANAGEMENT

\begin{tabular}{|c|c|c|c|c|c|c|}
\hline $\begin{array}{l}\text { 1. MITRE: } \\
\text { Public Policy } \\
\text { Conference }\end{array}$ & $\begin{array}{l}\text { 2. EPA: } \\
\text { Criteria Workshop }\end{array}$ & $\begin{array}{l}\text { 3. EPA: } \\
\text { Criteria Forum }\end{array}$ & $\begin{array}{l}\text { 4. DOE: } \\
\text { WIPP (Pilot Plant) } \\
\text { Public Meet ings }\end{array}$ & $\begin{array}{l}\text { 5. IRG: } \\
\text { Meet ings }\end{array}$ & $\begin{array}{l}\text { 6. r.nNGRESS } \\
\text { WIPP (PIlot Plant) } \\
\text { Oversioht Hearings }\end{array}$ & $\begin{array}{l}\text { 7. DOE: : } \\
\text { Generic } \\
\text { Fnvironmental } \\
\text { Impart. (GiFIs) } \\
\text { Hearinas }\end{array}$ \\
\hline $\begin{array}{l}\text { John Busterond/CEQ } \\
\text { Glen Groves/NSF }\end{array}$ & $\begin{array}{l}\text { W.D. Rowe } \\
\text { Office of Radiation } \\
\text { Programs }\end{array}$ & $\begin{array}{l}\text { W.D. Rowe } \\
\text { Office of Radiation } \\
\text { Programs. }\end{array}$ & $\begin{array}{l}\text { John 0'Leary } \\
\text { Dept. Sec. DOE } \\
\text { John Deutsch, Director } \\
\text { Office of Research }\end{array}$ & $\begin{array}{l}\text { John Deutsch, Chairman } \\
\text { IRG }\end{array}$ & $\begin{array}{l}\text { Harold Runnels, } \\
\text { Chairman, Suh- } \\
\text { Committee on Over- } \\
\text { sight Invest Igat- } \\
\text { ions House Comm. } \\
\text { Ins. Affairs }\end{array}$ & $\begin{array}{l}\text { Colin Heath, Asst. } \\
\text { nir. Office of Haste } \\
\text { Isolation } \\
\text { nffice of Muclear } \\
\text { Waste Manaqement. }\end{array}$ \\
\hline $\begin{array}{l}\text { Oct. } 27-29 \\
1976\end{array}$ & $\begin{array}{l}\text { Apri1 12-14 } \\
1977\end{array}$ & $\begin{array}{l}\text { March 30- } \\
\text { Apri1 1, } 1978\end{array}$ & $\begin{array}{ll}\text { Apri11 11, } & 1978 \\
\text { Apri1 } 12, & 1978\end{array}$ & $\begin{array}{l}\text { July/August } \\
1978\end{array}$ & $\begin{array}{l}\text { August } 8 \\
\text { August } 10,1979\end{array}$ & $\begin{array}{l}\text { June-nctoher } \\
1970\end{array}$ \\
\hline Chicago & Albuquerque & Denver & $\begin{array}{l}\text { Albuquerque } \\
\text { and Carlsbad }\end{array}$ & $\begin{array}{l}\text { Boston } \\
\text { San Francisco } \\
\text { Denver }\end{array}$ & $\begin{array}{l}\text { Carlsbad and } \\
\text { Albuquerque }\end{array}$ & $\begin{array}{l}\text { Washington } \\
\text { Chicaqo } \\
\text { At lanta } \\
\text { Dallas }\end{array}$ \\
\hline 453 participants & 218 participants & 27 participants & 61 participants & 729 participants & 25 participants & 219 particinants \\
\hline
\end{tabular}


full range of the public. Two theories about the type of participant likely to be involved in disproportionate numbers exist. One (Mills, 1956 and McConnel, 1972) holds that meetings are likely to be dominated by experts, representatives of the nuclear industry, and federal officials. Individual citizens and citizen groups are likely to be underrepresented. Another view (Wildavsky, 1976 and Tucker, 1977) holds that individual citizens and citizen groups will be overrepresented, with experts, nuclear industry representatives, and federal officials present in fewer numbers.

White (1966), for instance, argues that public meetings are very likely to reflect known views of identified industry groups and experts. Similarly, in analyzing a public meeting on water quality standards, Fox and Wible (1973) note that the organized waste dischargers had a "more active voice." These theories maintain that the established clientele of a particular government agency will dominate public meetings. Because notices regarding public meetings frequently are obscure, members of the general public will be less aware of meetings. In comparison with industry groups and experts, they will have less input and correspondingly less influence. In addition, while organized interests normally have a clear focus on the issues which affect their members, ordinary citizens are likely to have other concerns that take precedence. As a consequence, public meetings will be dominated by organized interests. 
Another theory holds that individual citizens or their representatives will dominate. Citizen groups are frequently made up of individuals with no immediate material interest in the cause that they advocate (Schattschneider 1960). The individual citizen or spokesperson for a citizen group is likely to: (1) personally believe the issue is important; (2) be able to free him or herself from competing demands during the time of the hearing; (3) consider him or herself a "responsible citizen;" (4) be knowledgeable to a greater or lesser extent about the issues to be discussed; and (5) believe that his or her presence or input can have an impact. Although private citizens and citizen groups may be uninformed about the technical details of an issue, they are likely to be knowledgeable and eager to play a role.

\section{Concerns}

An understanding of the concerns of participants provides convenors with a basis to anticipate the nature and the scope of the testimony that will be presented. Examples of some of the more common concerns of participants include:

(I) Receiving information. A participant may give testimony, but the primary reason for being at the meeting may be to acquire information. 
(2) Providing information. Participants, on the other hand, may have as their primary purpose the provision of information either on the specific issues discussed at the meeting, or on the subject matter generally. A participant may direct the information either to agency decision makers or to the media.

(3) Showing support for or opposition to government policies. In addition to providing information and receiving it, participants may be prompted by the desire to support or oppose government policies.

(4) Establishing a record for later efforts. Participants may desire to establish a record for a position which will support later efforts. Consequently, participants may submit information or make statements that do not appear immediately relevant to the subject matter.

(5) Attracting attention. The need to attract attention may be a reason for "public interest" participation (Marcus, 1979). Adopting extreme positions that threaten "vested interests" and stir controversy attracts attention. According to Walker (1981), "these abrasive tactics are. - . more effective in raising issues than resolving them. . ." Public 
interest leaders try to appear as "purists," as those with integrity opposing "vested" and "monied" interests in order to enjoy symbolic victories which give them leverage and good standing for future struggles (Marcus, 1979).

(6) Preventing resolution of an issue. Delaying resolution of the issue may be an important concern of some participants. "Stonewalling" is a common strategy of business corporations when confronted with certain kinds of government regulation. Rankin and Nealey (1981) have found that environmentalists as a whole do not strongly support siting options for nuclear waste. Coupled with their opposition to nuclear power generally, they are likely to oppose any specific siting proposal.

(7) Maintaining citizen control. Citizens and citizen groups may be skeptical of the promised benefits of a technology, fear the worst in the way of harms, and doubt expert willingness and capacity to contain the technology (Goggin, 1981). They may therefore want to democratize the decision making process, justifying their stand primarily on the grounds that citizens democratic rights mandate access of the lay public to authoritative "scientific" decisions. 
Convenors such as the DOE are likely to have different concerns than the participants. Their concerns have been described in Chapter 2, and consist of the following:

- Obtaining information.

- Providing information.

- Legitimation.

- Public acceptance.

Concerns of participants are more likely to diverge from concerns of convenors than they are likely to match these concerns. (See Table 2.) An example of matching of concerns is when convenors seek information and participants are primarily interested in providing it. An example of divergence is when convenors are trying to achieve public acceptance, while participants are trying to prevent resolution of an issue. Divergent concerns can be a critical problem in the conduct of public meetings. It should be emphasized that efforts can be made to harmonize divergent concerns and that these efforts can have an important effect on the meeting outcome. An effort that can be taken to structure meetings to minimize conflict will be discussed in the final section of this Chapter, page 41. (Also see Appendix 2: Organization, Purpose and Format of Past Nuclear waste Meetings.)

\section{Analysis of Past Meetings}

This section, based on an analysis of published reports of past meetings, discusses the pattern of participation. Seven 
TABLE 2: CONVENOR AND PARTICIPANTS CONCERNS

CONVENOR CONCERNS

\begin{tabular}{|c|c|c|c|}
\hline $\begin{array}{l}\text { PARTICIPANT } \\
\frac{\text { CONCERNS }}{}\end{array}$ & $\begin{array}{l}\text { Provide and } \\
\text { receive } \\
\text { information }\end{array}$ & $\begin{array}{l}\text { Legitimi- } \\
\text { zation }\end{array}$ & $\begin{array}{l}\text { Public } \\
\text { acceptance }\end{array}$ \\
\hline $\begin{array}{l}\text { Provide and } \\
\text { receive infor- } \\
\text { mation }\end{array}$ & + & - & + \\
\hline $\begin{array}{l}\text { Show support } \\
\text { or opposition }\end{array}$ & - & + & + \\
\hline $\begin{array}{l}\text { Establish a } \\
\text { record for } \\
\text { further action }\end{array}$ & + & + & - \\
\hline $\begin{array}{l}\text { Attract } \\
\text { attention }\end{array}$ & - & + & - \\
\hline $\begin{array}{l}\text { Prevent } \\
\text { resolution } \\
\text { of issue }\end{array}$ & - & - & - \\
\hline $\begin{array}{r}\text { Exercise } \\
\text { citizen } \\
\text { control }\end{array}$ & - & + & - \\
\hline
\end{tabular}

Code: + probable match between concerns of convenors and participants;

- probable mismatch between concerns 
earlier meetings are analyzed (see Table 1). The seven public meetings, dates, places, convenors, and number of participants are listed in the Table. Two of the meetings were convened by interagency committees, two by EPA, two by the Department of Energy, and one by Congress. The names of the convenors and their affiliation are listed in Table 1 . Some of the meetings were held in a single city at a single date. Others involved a series of meetings in a number of places over an extended period of time. The number of participants in the meetings ranged from 27 to 729, with a median of around 200 participants. Participation at these meetings will be analyzed with further discussion of the meetings provided in Appendix 2.

\section{a. Participants}

Seven types of participants may be distinguished: (See Table 3.)

(1) The nuclear industry and utilities includes manufacturers of nuclear power plants, construction and engineering companies involved in the nuclear business, the trade associations and research organizations of the nuclear industry, the radiation monitoring and detection industry, utilities that buy and run nuclear power plants, and private companies that transport and store waste. 
TABLE 3: PARTICIPATION AT NUCLEAR WASTE MEETINGS*

\begin{tabular}{|c|c|c|c|c|c|c|c|}
\hline & $\begin{array}{l}1976 \\
\text { MITRE: } \\
\text { Pubilc } \\
\text { Policy } \\
\text { Conference } \\
\quad x\end{array}$ & $\begin{array}{l}\text { 1977 } \\
\text { EPA: } \\
\text { Criteria } \\
\text { Workshop } \\
\quad x\end{array}$ & $\begin{array}{l}1978 \\
\text { EPA: } \\
\text { Criteria } \\
\text { Forum } \\
\quad x\end{array}$ & $\begin{array}{l}1978 \\
\text { DOE : } \\
\text { WIPP } \\
\text { Meet ings } \\
\quad x\end{array}$ & $\begin{array}{l}\text { 1978 } \\
\text { IRG: } \\
\text { Public } \\
\text { Review } \\
x\end{array}$ & $\begin{array}{l}1970 \\
\text { Conaress: } \\
\text { WIPP } \\
\text { Hearinas } \\
\quad x\end{array}$ & $\begin{array}{l}1079 \\
\text { DOF : } \\
\text { GE ISS } \\
\text { Hearinas } \\
\quad *\end{array}$ \\
\hline Wuclear Industry & 20 & 16 & 12 & 0 & 9 & 8 & 9 \\
\hline Federal Goverment & 16 & 15 & 12 & 16 & 2 & 20 & 9 \\
\hline $\begin{array}{l}\text { State and Local } \\
\text { Government }\end{array}$ & 7 & 8 & 3 & 12 & 5 & 33 & 17 \\
\hline Citizen Groups & 7 & 8 & 33 & 21 & 32 & 25 & 4.5 \\
\hline Experts & 30 & 20 & 33 & 5 & 14 & 5 & 4.5 \\
\hline $\begin{array}{l}\text { Other Economic } \\
\text { Interests }\end{array}$ & 9 & 13 & 0 & 2 & $5^{\circ}$ & 8 & $n$ \\
\hline Individuals & 11 & 10 & 7 & 44 & 27 & 0 & 56 \\
\hline
\end{tabular}

* The information is expressed for each participant category as the percentage of the total attendees at the meeting. The sources for the percentages are: Mitre, 1976; EPA, 1977; EPA, 1978; DOE, 1978; Interagency Revlew.Group, 1979; House Committee, 1979; and DOE, 1980. 
(2) The federal government includes Congressmen and Senators, officials from the Department of Energy, the Department of Interior, EPA, the United States Geologic Survey, the Nuclear Regulatory Commission, and other agencies and departments.

(3) State and Iocal government includes mayors, county commissioners, governors, and state government civil servants (responsible for protecting health, promoting housing, and other activities).

(4) Citizen groups includes organizations of citizens that are both pro- and anti-nuclear. Citizen groups are frequentIy as organizations "composed of individuals (like organizations of those opposed to capital punishment) where the individuals are not likely to benefit directly from policies they favor (in the case of the anti-capital punishment organization because they do not themselves face execution). Citizen groups have various names such as "Nuclear waste Forum," "Citizens for Energy Development," "Citizens Opposed to Nuclear Waste Disposal," (House Hearings, 1979) and so on.

(5) Experts include academics with university affiliations, private consultants, and research scientists and managers at government or privately run laboratories. 
(6) Other economic interests include individuals from the financial community, labor unions, law firms, and business corporations, and other interests not directly involved in nuclear power development, waste storage, or generation. A business may, for example, have an interest in developing the minerals on a piece of land being considered for a nuclear waste storage site, and therefore will seek to give testimony.

(7) If an organizational affiliation is not attached, it is assumed that the person participated as an individual, not as a member of an organized group. The seventh category of participant in Table 2 is individuals.

We have examined documentary evidence (see Table 3) from each meeting which lists participants--attendees who merely showed up and/or those who gave formal testimony and submitted statements. In each case the document gives an organizational affiliation, if one exists, for each participant. The data show that individuals were an absolute majority at the 1979 GEIS Hearings, and a relative majority at the DOE/WIPP Meetings of 1978. The IRG public review of 1978 also had a relatively high (one-quarter) participation by individuals.

The data show that citizen group participation increased from under 10 percent in meetings before 1978 to greater than 20 
percent in meetings after 1978 (with the exception of GEIS). State and local government participation also increased after 1978.

The data show a trend from participation by disproportionate numbers of experts, nuclear industry representatives and federal government officials to participation by disproportionate numbers of individuals, citizen groups, and state and local officials. (See Table 4.) A "dominant faction" may be defined as the smallest number of participant groups with similar objectives and, together, constitute the greatest number of participants at a meeting. Thus, at the MITRE Public Policy Conference, experts, nuclear industry, and the federal government are the smallest number of participant categories with roughly similar objectives to constitute a majority. Some meetings are dominated by factions composed of experts, the nuclear industry and the federal government, while other meetings are dominated by factions composed of individuals, citizen groups, and state and local governments.

These differences in "dominant faction" suggest a number of interpretations:

(1) The purpose of meetings may dictates different patterns of participation. When broad concerns in public policy or criteria documents are the main agenda-item, meetings are limited to experts, government officials, and the nuclear industry; however, when specific impacts on a community or 
TABLE 4: DOMINANT FACTIONS AT PAST PUBLIC MEETINGS

MEETING
Mitre: Public
Policy Conference
EPA: Criteria
WOrkshop
EPA: Criteria
For un
DOE: WIPP
Meetings
IRG: Public
Review
Congress: WIPP
Bearings
DOE: GEISS
Bearings

YEAR

1976

1977

1978

1978

1978

1979

1979
DOMINANT FACTION

Experts/Nuclear

Industry/Federal

Government

Experts/Nuclear

Industry/Federal

Government

Experts/Citizen

Groups

Individuals/Citizen

Groups

Citizen Groups/

Individuals

State and local

government/

Citizen groups

Individuals/state

and local government
PERCENTAGE

66

51

66

65

59

58

73 
public review are involved, participation was broadened to include citizen groups, individuals, and state and local officials.

(2) Participation in the late 1970s may have expanded to include individuals and groups that were in the past underrepresented. This broadening of participation would corroborate, in turn, the theory of organized interest dominance, and the theory of citizen or citizen group dominance.

(3) A group often ignored in discussions of participation is state and local officials. Their participation appears to be correlated with the participation of individuals and citizen groups, but it may follow its own pattern, being related to how project specific the meetings are or some other variable.

(4) The data indicate that a cyclical pattern in public meeting participation prevails over time. Public participation in meetings is a process that takes place over years under varying circumstances. In the course of resolving complex and controversial technical issues, government officials have the chance to hear the opinions of individuals and citizen groups and the opinions of organized interests and the federal government. 
(5) Planning the participation process, then, by arranging different types of meetings for different groups of participants may be appropriate. In an article in the Public Administration Review, Kauffman and Shorett (1977) suggest such a strategy for public involvement in water management. A similar approach is relevant to nuclear waste.

An important question for arrangers of meetings to consider is, given the history of past participation, how broad should current participation be so as not to violate convenor concerns. This question is addressed in the fourth section of this chapter, where arguments for and against broader participation are considered.

\section{Pattern of Participation}

The character of meetings is, of course, partially dependent on the particular pattern of participation. For instance, more of the participants at the IRG and GEIS meetings were individuals, citizen group representatives, and state and local officials. Coalitions of these participants are likely to express opposition to nuclear power generally (see Table 5), or to take up policy issues such as opposition to siting a repository in a given area or particular region (see Appendix 2). Individuals have been observed (Slovic, 1976) as 
Table 5: Concerns of IRG Participants*

\begin{tabular}{cccccc}
$\begin{array}{l}\text { Federal } \\
\text { Involvement }\end{array}$ & $\begin{array}{l}\text { Anti-Nuclear } \\
\text { Comments }\end{array}$ & $\begin{array}{l}\text { Alternative } \\
\text { Technology } \\
\text { Strategies }\end{array}$ & $\begin{array}{l}\text { Pro-Nuclear } \\
\text { Comments }\end{array}$ & $\begin{array}{l}\text { Spent } \\
\text { Fuel }\end{array}$ & $\begin{array}{c}\text { Transportation } \\
40\end{array}$ \\
\hline 17 & 49 & 36 & 12 & 14 & 8 \\
42 & 12 & 19 & 9 & 8 & 3 \\
30 & 2 & 16 & 11 & 8 & 3 \\
20 & 12 & 12 & 7 & 4 & 8 \\
11 & 6 & 10 & 1 & 1 & 3 \\
4 & 1 & 4 & 1 & 3 & 0
\end{tabular}

$\begin{array}{lllll}\text { TOTALS } & 163 & 159 & 140 & 53\end{array}$

$42 \quad 39$

*Based on IRG content analysis, IRG, 1979. 
being more concerned with general values and attitudes, and less concerned about specific technical issues and uncertainties. Representatives of the federal government, the nuclear industry and utilities, and academic experts, on the other hand, are more likely to consider technical issues (see Table 6).

Individual attitude towards risk, may be governed by three variables: (1) whether the individual thinks he or she controls the risk; (2) whether the hazard shows up as a "single big event" or a series of small independent events; and (3) whether the risk is familiar and easily understandable or unfamiliar and extremely complex (Dupont, 1981). Representatives of the federal government, the nuclear industry, and experts are more likely to: (1) feel that they have greater control over a technology; (2) understand the difference between a "single big event" and a series of individual ones; and (3) find the technology familiar and understandable. The nature of participants then, will affect the character of meetings. Greater participation by unaffiliated individuals, citizen groups, and state and local governments, is likely to lead to increased discussion of nuclear issues generally; while greater participation by nuclear industry representatives, government officials, and academic experts is likely to lead to increased discussion of technical matters (see Table 7).

Those organizing nuclear waste hearings should be aware that the pattern of participation influences the character of meetings. If the result they seek is a discussion of the 
Table 6: Concerns of EIS Participants*

NON-TECHNICAL

Policy Issues and

General Comments
$\mathrm{T}$

\section{Consequence} Analysis

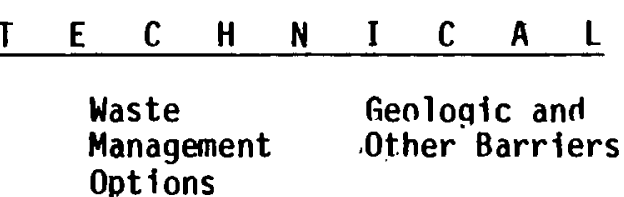

Alternative

Disposal

Concepts

\begin{tabular}{|c|c|c|c|c|c|}
\hline Individuals & 106 & 18 & 9 & 20 & 9 \\
\hline $\begin{array}{l}\text { State and Local } \\
\text { Government }\end{array}$ & 26 & 9 & 5 & 7 & 6 \\
\hline Federal Government & 10 & 5 & 4 & 5 & 6 \\
\hline $\begin{array}{l}\text { Nuclear Individuals } \\
\text { and Utilities }\end{array}$ & 18 & 10 & 6 & 9 & 6 \\
\hline Citizen Groups & 9 & 4 & 1 & 4 & 0 \\
\hline Academic Experts & 8 & 3 & 2 & 5 & $?$ \\
\hline TOTALS & 177 & 49 & 27 & 50 & 29 \\
\hline
\end{tabular}


Table 7: Ratio Between Nontechnical and Technical Issues Among Participants At GEIS Meetings*

\begin{abstract}
Nontechnical (NT) = Policy Issues and General Comnents
Technical $(T)=$ Geologic and Other Barriers, Consequence Analysis, Alternative Disposal Concepts and Waste Management Operations
\end{abstract}

$\underline{N T / T}$

INDIVIDUALS

STATE AND LOCAL GOVERNMENTS

FEDERAL GOVERNMENT

NUCLEAR INDUSTRY AND UTILITIES

CITIZEN GROUPS

ACADEMIC EXPERIS

*Developed from Table 6.

P15465

$4148 \mathrm{X}$
1.9

1.0

.5

.6

1.0

.7 
nuclear power issue generally, then they should try to arrange meetings so that a preponderence of participants are individuals from the general public. If the result they seek is a discussion of technical issues, they should try to arrange meetings so that a preponderance of participants are from the nuclear industry, government, and research institutions.

\section{Should Participation Be Limited?}

Number and kind of participants influence the character of meetings. Should meetings be limited in number or type of participants or should they be broadened to include a larger number of potential participants?

Arguments for limiting participation include the following:

(1) Who is the "public?" Even if given the opportunity for meaningful involvement, a high percentage of people are not likely to participate. Presumably, most people do not want to participate. Leaders of industry and of big business and activists organizations--dedicated to environmental and other causes--will fill the vacuum. Each will claim that it alone represents the "public." Indeed, "each does represent a significant fraction of the total public, but no particular fraction can claim the title the public." (Bishop, Hoos, et al., 1978). Thus, it is incumbent upon convenors of a meeting to choose a 
particular "public," and to limit participation to a particular class or group of people based on the function of the meeting and what it aims to accomplish.

(2) Inefficiency and chaos. A second argument for limiting participation is the inefficiency and chaos of large public meetings. Mass involvement may result in the disintegration of consensus and may overburden the government with demands it cannot fulfill. Such large meetings, where there are many participants with conflicting points of view, does not aid in rational decisionmaking.

(3) Complexity. Further, it is argued that increased participation lowers the quality of technical decisions, because new participants lack the knowledge essential for informed participation. Many policy issues concerning complex technologies are likely to be beyond the grasp of the general public. For example, submissions by public interest groups to regulatory proceedings are of ten composed without access to the relevant data (Schuck, 1977). The data base of public interest groups, in comparison with industry and regulators, is relatively poor. Public interest groups therefore must "seek to discredit industry statistics, of ten without alternative data 
sources of high quality, or take the industry data as given and seek to draw contrary inferences from it" (Schuck, 1977). Increased participation therefore may lead to obstruction, rather than the orderly resolution of issues.

These arguments against participation are countered by the following arguments for broader participation:

(1) Accessibility. Citizen groups, individual, and state and local governments generally do not enjoy accessibility to public forums because they lack resources and information. Schuck writes that public interest groups are "without the resources to hire expert specialists, without enough lawyers to endure incredibly protracted proceedings, without access to high quality information (or even good library sources), . . (and) compelled to rely on the services of inexperienced generalists who will soon be forced by economic necessity to move on to other things" (Schuck, 1977). Individual or public interest group participation in agency proceedings, according to this argument, is possible only on a sporadic or ad hoc basis, and therefore should be encouraged, not stifled. 
(2) Broad value issues. Another point in favor of increased participation is that it can make an important contribution when broad value issues are at stake. In cases where understanding of the issue is so unclear that it is debatable which group of technical experts are relevant, increased participation can be helpful (Orr, 1979). Also, value choices, for which there are no experts, may require participation by a broad public.

(3) Implementation. John Stuart Mill (as cited in Orr, 1977) remarked that participation alters outlook and behavior and encourages greater awareness and involvement. Increased participation can lead to greater involvement in implementation, and thus may facilitate the achievement of project goals.

(4) Equity. Costs and risk of energy policy are not random and may fall most heavily on those least able to participate in decision making (Orr, 1979). Greater participation, therefore, may be justified in order to promote equity in the distribution of impacts.

(5) Tailor Meetings to Achieve Particular Results.

Airing of grievances without resolution attracts attention and creates controversy and may be unappropriate for some 
meetings, so that choice has to be made in regard to format as well as participants. In comparison with the EPA convened meetings, that ended with joint position papers stressing areas of agreement about specific topics, the DOE convened meetings generally had "moments of tension" (see Appendix 2). EPA had smaller meetings, their purpose was different, and participation was limited to different groups; but in regard to the harmony with which the meetings ended an important factor was the use of a different format-"the working group technique." After sufficient knowledge about issues was provided through prepared papers and speeches, participants were divided into "working groups," where efforts were made to develop areas of common agreement. In contrast to the DOE meetings, the EPA meetings did not end in confrontational question and answer sessions. Meetings can be arranged so that they achieve consensus or emphasize conflict. Those organizing them should tailor format and agenda to achieve particular results (Schilling and Nealey, 1979). 


\section{REFERENCES}

Bishop, W.P., Hoos, I.R., et al. Essays on issues relevant to the regulation of radioactive waste management. NUREG-0412. 1978.

EPA. Proceedings: a workshop on policy and technical issues pertinent to the development of environmental protection criteria for radioactive wastes. 1977.

EPA. Public for um on environmental protection criteria for radioactive wastes. 1978.

DOE. Final environmental impact statement--public comments hearing board report. 1980 .

DOE. Public meeting on nuclear waste disposal. 1978.

Dupont, R.L. The nuclear power phobia. Business Week. September 7, 1981 .

Fox and Wible. Information generation and communication to establish environmental quality objectives. Natural Resources Journal, 1973, 13, 134-149.

Goggin, M.L. Science policy governance. Paper presented at American Political Science Association Meeting. September 1981.

House Committee on Interior and Insular Affairs. Nuclear waste isolation plant oversight hearings, 1979.

Interagency Review Group. Report to the President. 1979.

Rauffman, R. and Shorett, A. A perspective on public involvement in water management decision making. Public Administration Review, September/October 1977.

Marcus, A.A. Public interest leaders. Business Horizons, August 1979 .

McConnel, G. Private power and American democracy, 1972.

Mills, C.W. The power elite, 1956.

MITRE. Proceedings of conference on public policy issues in nuclear waste management, 1976.

Orr, D.W. U.S. energy policy and the political economy of participation. The Journal of Politics, 1979. 
Slovic, P. Psychological factors in the perception and acceptability of risk: implications for nuclear waste management, proceedings of the conference on public policy issues in nuclear waste management, 1976.

Schilling, A.H. and Nealey, S.M. Public participation in nuclear waste management. April 1979.

Tucker, W. Environmentalism and the leisure class. Harpers, December 1977.

Rankin, W. and Nealey, S. Public concerns and choices regarding nuclear waste repositories. Battelle HARC report. June 1981.

Schattschneider, E.E. The semisovereign people, 1960.

Shuck, P. Public interest groups and the policy process. Public Administration Review (March/April), 1977.

Verba, S. and Nie, N. Participation in America, 1972.

White, G. Formation and role of public attitudes. In H. Jarret (Ed.), Environmental quality in a growing economy, 1966.

Walker, J.L. The origins and maintenance of interest groups in America. Paper presented at the annual meeting of the American Political Science Association, September 1981.

Wildavsky, A. Aesthetic power, or the triumph of the sensitive minority over the vulgar mass. Daedalus, Fall 1969. 
CHAPTER 4

Organization and Management

of public Meetings on Nuclear waste

A public meeting's success or failure is not absolute. Rather it depends on the meeting's functions and the objectives of the participants. A meeting is successful for its sponsor if it achieves the functions for which it was organized. Participants, however, will arrive at different conclusions concerning the success of a public meeting depending on their own objectives for attending the meeting. Consequently, it is not possible for the DOE to structure a public meeting so that it will be universally considered a success. However, the DOE can organize meetings so that its functions for the meeting will have a significant chance of being realized. Public meetings, as distinct from public hearings, enjoy a large degree of flexibility in their administration. Accordingly, the DOE has the opportunity early in the preparation for a public meeting to begin shaping the relevant elements to insure the meeting's functions are attained. This effort must reflect the nature of the meeting and the characteristics of the affected participants. The DOE can facilitate public participation by structuring particular elements of a meeting to be compatible with the meeting's nature and to accommodate the expected attendees. Moreover, panel members, moderator and other participating officials can 
better prepare for their roles if they enjoy an understanding of the nature of the meeting and its expected attendees. Following is a discussion of the various elements to a public meeting which the DOE can influence in order to facilitate public participation. The meeting elements are presented according to whether they occur prior to, during, or after the public meeting. None of the elements are consistently relevant. Their usefulness depends on the functions for the meeting, its nature and the characteristics of the expected participants. While several of the options will increase public participation or enhance some function of the meeting, they might be advisable only in rare instances because of the associated problems they may create.

The meeting functions that are primarily affected by each particular element will be highlighted. (See Table 8). It may be initially expected that structuring an element to enhance one function potentially would disturb another of the meeting's functions. However, a close inspection reveals that where an element is shaped to enhance one function, it almost universally aids or has no affect on the other functions. Only rarely does such an action create the potential to negatively affect another meeting function.

For clarity, this discussion addresses each element independently. However, it is the meeting in its entirety that will determine whether the designated functions are accomplished. Consequently, focusing on each element 
individually is insufficient. Rather, an effort should be extended to insure that the various elements complement one another. 
TABLE 8

MEETING ELEMENTS RELEVENT

TO DOE FUNCTIONS

M E E T I N G F U N C T I O N
A. ELEMENTS PRECEEDING
THE PUBLIC MEETINGS
Provide
Obtain
Information
Information Legitimate
Public
Acceptance

Secure

\begin{tabular}{|c|c|c|c|c|c|}
\hline 1. & $\begin{array}{l}\text { Notification of } \\
\text { Potential Participants }\end{array}$ & $x$ & $x$ & $x$ & $\mathrm{x}$ \\
\hline$\overline{2 .}$ & $\begin{array}{l}\text { Timing and Contents } \\
\text { of Meeting Notice }\end{array}$ & & $x$ & $x$ & $x$ \\
\hline 3. & $\begin{array}{l}\text { Identification of } \\
\text { Participants }\end{array}$ & $x$ & $x$ & & $x$ \\
\hline 4 & $\begin{array}{l}\text { Location of Back- } \\
\text { ground Information }\end{array}$ & $x$ & $x$ & & \\
\hline $5 \cdot$ & $\begin{array}{l}\text { Invitation of and } \\
\text { Provision of Expenses } \\
\text { for Designated } \\
\text { Participants }\end{array}$ & & $x$ & & \\
\hline$\overline{6 .}$ & $\begin{array}{l}\text { Assistance in Prep- } \\
\text { aration of Testimony }\end{array}$ & & $x$ & & \\
\hline & Written Comments & & $\mathrm{x}$ & & $x$ \\
\hline 8 & $\begin{array}{l}\text { Pre-Meeting } \\
\text { Workshop }\end{array}$ & & $x$ & $x$ & $x$ \\
\hline B. & MEETING ELEMENTS & & & & \\
\hline & $\begin{array}{l}\text { Location of Meeting } \\
\text { Site }\end{array}$ & $x$ & $x$ & $\mathbf{x}$ & $x$ \\
\hline 2. & $\begin{array}{l}\text { Timing of the } \\
\text { Meeting }\end{array}$ & $\mathrm{x}$ & $x$ & $x$ & $\mathrm{X}$ \\
\hline
\end{tabular}



A. ELEMENTS PRECEEDING
Provide
Obtain
Secure
THE PUBLIC MEETINGS
Information
Information
Public
Acceptance

3. Format of the

Meeting

$\mathrm{X}$

$\mathrm{x}$

$\mathrm{X}$

$\mathrm{X}$

4. Moderator

5. Panel

X $x$

6. DOE Personnel Attending the Meeting

$x$

$\mathrm{x}$

D. POST-MEETING

ELEMENTS

1. Record of Testimony

$x$

2. Summary of Testimony

$\mathrm{x}$

$\mathrm{x}$

3. Written Testimony Sub-

mitted After Meeting

$\mathrm{x}$

$x$

4. Post Meeting

Wor kshops

$\mathrm{x}$

$\mathrm{x}$ 
A. Elements Preceding the Public Meeting.

The following activities that must be completed prior to a public meeting can significantly influence the quality of the public participation evidenced at the meeting.

1. Notification of Potential Participants

Relevant Functions

All four functions are assisted by an energetic effort to notify interested parties of the public meeting. The act of notification itself, enhances the legitimation function, regardless of the public attracted. Moreover, where the meeting is properly conducted, the large attendance representing a variety of interests and organizations resulting from a successful notification effort assists in the provision and collection of information and increases the probability of securing public acceptance for any governmental action proposed by the agency sponsoring the meeting.

The identification and notification of the appropriate "public" that is to be involved is a useful but difficult task. By its very nature, the public is diffuse and highly segmented into special interest groups, geographic communities, and individuals. The general question is "who are the publics that should be involved and how can they be notified?" 
DOE can supplement legally required notification procedures, such as publication of notice in the Federal Register, and the other procedures it regularly follows, such as providing a news release to local radio and television stations, by directly contacting public interest groups, trade associations and other organizations. While the organizations notified generally should consist of those with interests and experience which relate to the subject area and the scale of the meeting, an effort should be extended to also include organizations with a general concern for the subject matter, as well as those which already have raised specific issues. For instance, notification of a public meeting concerning a local relocation and stabilization of mill tailings under the Uranium Mill Tailing Radiation Control Act should include chambers of commerce and citizen land-use organizations, as well as regional branches of environmental organizations and industrial associations interested in mill tailings radiation.

If it has not been possible to develop a contact list during the early planning for the federal action that is a basis for the public meeting, a suitable list frequently can be prepared from the direct mailing lists of various interest groups and trade associations readily identifiable as having an interest in the subject matter. An established neutral group, such as the League of women Voters, can be utilized to compose the list and notify the 
included parties of the meeting. The actual organization selected for this task should have an interest that corresponds to the subject of the meeting and a perspective that corresponds to the meeting's scale.

2. Timing and Contents of Meeting Notice Relevant Functions

The timing of the notice can affect the quality of the information obtained at a meeting, the legitimacy of the ultimate agency action, and the public acceptance the meeting generates for the action. The initial contact should allow sufficient time for preparation by the participants if the DOE is concerned with receiving information. The meeting notice can also enhance the legitimacy function by issuing it sufficiently early to discourage the charge that the agency is 'railroading' a predetermined decision. Public acceptance also requires an early contact in order to develop rapport, demonstrate good faith and insure a large attendance. The contents of the notice can alert potential participants to the review documents necessary for review in order to adequately prepare for the meeting.

The initial notices of the public meeting should be published, and identified parties contacted, with sufficient time to prepare for the meeting, including the 
assimilation of background documents. The initial contact could range from one to several months prior to the meeting, depending on the following:

- Meeting Functions: If the meeting is to collect information or to generate public acceptance, the notice should be published earlier than if the function of the meeting includes only the provision of information or the legitimation of a course of action.

- The complexity of the subject matter and the scale of the public meeting. The more complex the subject matter and the larger the scale of the public meeting, the earlier the announcement should be made.

- The amount of the complexity of the background material. The greater the complexity of the background material, the more time necessary to assimilate this and the earlier the announcement should be made.

All notices and invitations to a public meeting should indicate that requests to provide testimony should be received by $D O E$ at some designated date several weeks before the meeting is held. Requests that are received after that time, or during the public meeting, can be accomodated to the extent that there is available time. 
The notice also can indicate the scale and subject matter of the meeting and location of background information to enable the participants to prepare for the meeting. The notice should be republished and each entity recontacted every month following the initial notification concluding with a final notification several weeks prior to the meeting.

3. Identification of Expected Participants Relevant Functions Identifying participants indirectly increases the probability of realizing the following functions: provision of information, collection of information and public acceptance. Estimation of the number of participant's and a prior knowledge of their characteristics allows the meeting to be specifically tailored for the expected audience in order to achieve the noted functions.

Without positive effort by the meeting sponsor, many groups necessary for the function of the meeting will not become involved until it is too late to satisfactorily account for their interests and needs. Simply waiting to see what groups and individuals appear at a public meeting is not appropriate for the administration of a public meeting. Prior knowledge of this information enables the meeting to be structured to be 
compatible with the expected participants and facilitates the preparation of an agenda of participants useful to meeting organizers, the press and panel members. A relatively easy means of securing this information is to include in the meeting notices the requirement that all who wish to testify must pre-register.

\section{Location of Background Information Relevant Functions} Proper location of background documents can assist the following functions: Provide information and obtain information. Background documents must be carefully located to facilitate their availability if the DOE is to receive input at the meeting useful to its decisionmaking. To a lesser extent, the location of background documents is also important so the public can become familiar with necessary material in order to better assimilate the concentrated information provided during the public meeting.

Background documents should be readily available to all potential participants. Where the documents are too lengthy to be sent to those who request copies, summaries should be provided. The total collection of documents should be provided at DOE regional and field offices, as well as at public libraries and other locations convenient to the site of the public meeting and the locus of the majority of the participants expected to attend. 
5. Invitation of and provision of expenses for designated participants.

Relevant Functions

The invitation of and provision of expenses for designated participants can enhance the probability of receiving useful information containing a variety of perspectives. While there are several concerns with this activity, it can be useful where it is critical to acquire information from a segment of the population that has proven to be underrepresented at other public meetings with the same subject matter and scale as the present meeting.

As opposed to merely providing direct notice, it sometimes may be advantageous to invite and reimburse the expenses of designated participants. Industry and trade association representatives receive expenses to intervene in public meetings and consequently this sector of the public sometimes can be overrepresented at a public meeting. Financing interest groups without the economic "deep pocket" of private sector representatives, arguably would balance the testimony provided at such public meetings.

An assessment of potential participants must be first undertaken in order to determine if the private sector in fact will be overrepresented and whether the nature of the meeting demands that there be a more balanced 
representation in attendance. This assessment can be accomplished by (1) an evaluation of the subject matter, scale and objectives of the meeting in order to determine the necessity for a balanced representation and (2) a review of the identity of the preregistrants, DOE's experience with similar meetings and, if in existence, a mailing list of parties interested in the action in order to identify the groups that will likely attend. If this evaluation suggests that inviting designated parties may be useful, there are several concerns that first should be reviewed prior to offering such support.

- First, of course, public meetings are constrained by limited budgets and the obligation to support participation by selected groups will further limit the funds available for the mandatory expenses of the meeting.

- Second, it is difficult to identify the organizations that should be invited in order to obtain a satisfactory cross section of participants.

- Finally, regardless of the fact that the effort is pursued in order to obtain a broad representation of views, it could be argued that reimbursing the expenses of select organizations will diminish the 
appearance of objectivity that is necessary for the general acceptance of any governmental action stemming from a public meeting.

The last two concerns, the identification of groups that should be invited and the loss of the appearance of objectivity, can be mitigated by requesting a recognized neutral group, such as the League of Women Voters, to identify organizations that should be invited to attend.

6. Assistance in the preparation of testimony Relevent Objectives

Assistance in the preparation of testimony can enhance the DOE's effort to obtain information.

During the preparation for the IRG meetings, DOE assisted organizations with limited resources in the preparation of their testimony. DOE publicized, and also directly notified interested organizations, that attorneys would be available for a limited duration at a location close to the designated meeting site. The attorneys were instructed to assist in the presentation of testimony, but to avoid influencing the substance or position that would be advanced by the various participants.

This activity could be repeated if the meeting function includes information collection and where a review of the scale, subject matter, and the pre-registered participants, as well as experience with meetings of similar nature, suggests that the participants will not 
have the resources or expertise to offer well-developed, concise testimony. In addition to increasing the likelihood that clear testimony will be presented, this activity partially relieves the financial burden placed on participants for developing testimony. It can also be criticized, however, as an inadvertant attempt by the DOE to influence public testimony and to co-opt the various participants.

7. Written Comments

\section{Relevant functions}

Written comments can increase the probability that the following objectives will be achieved: Public acceptance and obtain information. The submission of written comments will allow the DOE panel and other participants to prepare to respond to the expected public concerns in order to gain acceptance for the proposed action. The participants will also be better prepared by having an opportunity prior to the meeting to review the various concerns and thus provide more inciteful testimony during the meeting. The requirements to provide written comments, however, could discourage some groups with lesser resources from testifying. Other disadvantages are discussed below.

The amount of repetitious testimony can be decreased and the quality of testimony increased by requiring written comments prior to the meeting in order to be allowed to 
testify. The DOE should prepare a summary of these comments, which would be made publicly available several weeks prior to the meeting. A page limit and submittal date for such comments would have to be established and included in the notices of the meeting.

While such a procedure presents a ready means of informing and educating the participants, it is not without its shortcomings. It can be argued that such groups as trade associations with ample resources are able to provide extremely polished testimony, which consequently could be more influential in the decision making process than the testimony of other groups with less resources to provide written comments. In addition, the ability to review each other's comments before the public meeting could create a contentious atmosphere. If the meeting is not skillfully moderated, the participants likely will react to and rebut each other's comments, rather than expressly responding to the subject and scale of the meetings. This behavior could result in a significant increase in the meeting's length without a substantive improvement in the testimony presented. It would also decrease the likelihood that the meeting would function either to legitimate the governmental action or to secure public acceptance. 
8. Pre-Meeting Workshop

Relevant Functions

Pre-meeting workshops can assist in the realization of the following objectives: obtain information, legitimation and public acceptance. Pre-meeting workshops are established to provide at least a minimum understanding of essential issues. Improving the public's knowledge of the relevant issues presumably will produce higher quality information at the meeting. The establishment of pre-meeting workshops can enhance the agency's public image and where the workshop is successful, it can increase the public acceptance of the proposed action. The act of holding pre-meeting workshops can serve to enhance the legitimation function of the public meeting.

A pre-meeting workshop is another means of ensuring that prior to the scheduled meeting date, all pre-registered participants will have some minimum level of understanding of the subject matter scope and DOE objective for the meeting. Such workshops can be useful where informed public input is critical for the proposed governmental action and there is a wide disparity of expertise and experience among the expected participants. Such a workshop can consist of (1) presentations on the technical and policy background necessary in order to understand the meeting's subject matter and (2) an explanation of manner in which the information received 
during the public meeting will be integrated into the agency's decision making process. Care should be taken by all speakers at such a workshop to avoid jargon and to deliver their presentaton in lay terms. A complete description of the purpose and the content of the workshop should be included with the published notice of the meeting. While a pre-meeting workshop can be beneficial, DOE risks being accused of coopting the workshop participants, which would decrease the meeting's ability to satisfy a legitimizing function. There is also the possibility of raising issues prematurely and attracting media attention to such issues that have yet to be fully defined or developed. This result could negatively affect the ability of the meeting to garner public acceptance for the proposed action.

As an alternative to a pre-meeting workshop, local task forces may be particularly useful where the proposed governmental action is primarily regional or local in its expected impact. While task forces are a public participation technique in their own right, assistance in the formation of a local task force followed by the frequent and substantive interaction with it can result in a less contentious public meeting with higher quality testimony. It will not preclude local objections to all the alternative proposals for a designated governmental action. However, it does disourage wholesale refusal by 
local officials and citizens to cooperate with the DOE to solve the problems associated with the various alternatives.

B. Meetings Elements

The following elements of the public meeting can affect the probability of DOE realizing its objectives.

1. Location of the Meeting Site.

Relevant Functions

The location of the meeting site can affect the characteristics and number of public participants. Accordingly, it can influence the following objectives: Public acceptance, legitimizing, information collection and information dispersal.

The location of the public meeting depends significantly on the scope of the meeting and the public expected to attend. The location should differ, for instance, depending on whether the meeting relates to a regional program under consideration by the DOE, or concerns some site specific issues with a project under consideration. In the former case, the meeting generally should be at the most convenient location to the majority of the region's population. In the latter case, a site should be selected which is both close to the project and is also easily accessible by all local residents that are potentially affected by any governmental decision that may result from the meeting. 
Once the scope of the meeting is established and there is an understanding of the population expected to attend, the selection of the site should include a consideration of the following two factors:

- Whether the meeting should be held in on urban center or rural setting;

- The accessibility of the meeting site to a variety of transportation modes, such as airport, mass transportation and highway and automobile parking facilities.

Depending on the population that is expected to attend, the reputed safety of the neighborhood is also sometimes a consideration and can affect the attendance level.

2. Timing of the meeting

Relevent Functions

The timing of the meeting can affect all four of the DOE's objectives. Scheduling the meeting at a time to facilitate attendance by all who wish to participate increases the legitimacy of the subsequent governmental action and where the meeting is conducted properly, it can also enhance the public's acceptance of the action. The meeting can also influence the size and variety of the attending public and thus affect a meeting's function to either provide or collect information. 
The public meeting should be scheduled to provide all interested individuals an opportunity to participate. Consequently, where there is only one meeting, it should be held on a Saturday morning or weekday evening. When a series of meetings is planned, at least one of them should be held at either of such times. If a large number of the participants are expected to travel long distances, the meeting should be scheduled to facilitate their attendance and to correspond with the time schedules for the various transportation facilities.

3. Format of the meeting.

Relevant Functions

The format of the meeting can affect all four meeting functions. The manner in which the meeting should be tailored for the various functions is discussed below.

The meetings format should be selected to accomodate the scale of the meeting, the objective of the meeting, the number of expected participants and their various characteristics. Any meeting should begin with the identification of moderator, panel members and other DOE officials present. A presentation should then be provided on the subject matter, scope and objective of the meeting including a description of the governmental action, if any, that is under consideration. This presentation should be 
followed by request for statements by the participants. A summary is then provided by the proponent of the project on the meeting sponsor, if different from the proponent. While the participants frequently have various levels of expertise and understanding of the subject matter of the meeting, the Battelle staff has observed that the public attending the meeting generally enjoys a substantial understanding of the proposed governmental action. Thus, except where the meeting is specifically for providing information on the proposed action, only a general overview of the action is necessary. In fact, an overview is preferable to a more detailed discussion of the proposed action, since it minimally restricts the freedom of the DOE to reconsider and modify the specifics of the proposed action during the subsequent planning stages.

During the background discussion, public participants should be informed not only of the potential to impact decision making processes, but also the limitations of their efforts. Public input will be accepted by DOE and considered in good faith. The government action, however, could still disturb some interests. General realization of this basic fact could encourage the public to remain positively involved in the process, even if the potential outcomes are adverse to some interests. Following are suggested formats compatible with the various DOE objectives: 
i. Information Dissemination. Where the meeting is to inform the public of a particular DOE activity, the primary concern for the organization of the format is to present the information in a clear and concise manner suited to the characteristics of the expected attendees.

ii. Information collection. Where the public is to testify at the meeting, there are several possible formats. The particular format selected largely depends on the composition of the expected participants, which can be acquired from either a list of pre-registrants or knowledge of the individuals who attended similar meetings at locations comparable to the present site.

When the pre-registered participants are fairly sophisticated and can be expected to set forth views either in opposition or support of the governmental action, the testimony can be provided in front of the large meeting. However, where it is probable that the participants do not have a great deal of experience with providing testimony in public meetings or they are expected to provide particular information or request clarification on various aspects of governmental action--that is, a dialogue between DOE and participants is either expected or encouraged--the meeting should be divided into small groups. Each group would be supplied with an individual secretary/moderator responsible for the following: (1) organizing and, where necessary, clarifying the testimony; (2) moderating the dialogue between the participants; and (3) recording the information submitted. The testimony of each participant could be facilitated by the moderator writing the major points of his other presentation on a blackboard visible to the group.

The individual groups would reconvene after discussion is exhausted and each secretary/moderator would convey to the meeting at large a summary of the group's information. Where there is some concern for arriving at a consensus in the testimony of the participants, each secretary could attempt to ask the members to rank order the importance of the concerned information expressed in these small groups. Where the meeting is composed of both experienced and inexperienced participants, it might be best to hold two sessions. The first session would consist of those wishing to testify in front of the meeting at large, and would probably include the local, state and federal government officials in attendance. The second session would consist of the small group format described above. Where the meeting was too small or it was determined for other reasons not to divide into small groups, for instance, if a sufficient number of secretary/moderators cannot be supplied, testimony could still be recorded on a black-board in order to assist participants to develop their main points and to enable the public to comprehend the testimony. 
iii. Legitimating function. In order to legitimate a subsequent governmental action, it is necessary that the meeting provide the public an opportunity to review and comment upon the range of proposals for the action. A dialogue between public and sponsor, however, is not mandatory. Consequently, if DOE's only concern is to legitimate its ultimate decision, the meeting structure for submission of testimony need only resemble the arrangement proposed for information collection, supra.

iv. Public Acceptance. Public acceptance is best realized where a positive dialogue occurs between $D O E$ and a large public in attendance. Consequently, where the DOE wishes to secure public acceptance of a decision, it should structure the submission of testimony in a manner similar to that discussed for the objective to collect information.

Where the attendees are requested to submit statements, regardless of the meeting functions, the following concerns should be carefully considered by the DOE in order to facilitate a useful and expedient meeting.

- Testimony should be presented from a central location, such as a microphone at a podium. Presenting testimony from a central location precludes individuals from speaking simultaneously, a frequent problem where the subject matter and objective of the meeting creates a contentious atmosphere. Where the large meeting breaks up into smaller groups, however, testimony can be presented informally, at the discretion of its secretary/moderator.

- In order to encourage the greatest cross section of attendees to testify, exchanges between participants and with members of the panel must be carefully structured to prevent inexperienced parties from becoming inhibited and consequently refusing to testify. Generally, questions by either the public or the review panel directed at clarifying a participant's testimony should be permitted. The moderator, however, has the responsibility to determine whether the questions are for clarification or rather are cross examination of an issue. Unlike at a public hearing, where the questions are cross examination or adversarial in tone, there should be no obligation for the testifying party to respond, regardless of DOE's objectives for the meeting. 
Questions from the participants relating to a description or explanation of the subject matter of the meeting or the proposed governmental action should also be permitted. Such questions should be answered in good faith by attending DOE representatives. When relevant, such as at EIS scoping meetings; panel members, moderator and other officials present should emphasize that the governmental action has not been predetermined prior to the meeting, beyond the preparation of several alternatives for consideration. It should be stressed that final determination on or selection of alternatives to the action will be made after the public participation process is completed and the information it generates is considered.

(iv) Time Limits

In order to allow time for all parties to speak and to encourage the testimony to be precise, participants should be required to observe a definite time limit on testimony, such as 10 or 15 minutes per speaker. The notice publicizing the public meeting should indicate the length of time allowed for each speaker. It should also indicate that those individuals who do not submit a request to testify before the registration deadline may be limited to less time than allowed for those who registered.

4. Moder ator

Relevant Functions

The selection of the moderator is not significantly dependent on the objectives that DOE wishes to achieve. Rather, the characteristics of the expected audience are the major determinants that should be evaluated in order to select the moderator. 
The moderator for a public meeting should be neutral and not an advocate for any proposed governmental action under discussion. Selection should be made with regard to the nature of the meeting and the characteristics of the participants.

Where the subject matter of the meeting is particularly controversial and participants are polarized and expected to regard the proceedings critically, the moderator ideally should be from an independent organization or agency and have substantial training or experience in leading such a meeting. At a minimum, the moderator should not be responsible for the action under consideration. On balance, however, the moderator must also possess sufficient knowledge of the subject matter under discussion in order to adequately discharge his or her responsibilities. The moderator should also command sufficient authority so that decision makers within the DOE would respect and consider his statements.

Where the subject matter is not extremely controversial or a rapport exists between the participants and the DOE, the project moderator might be a key individual within the DOE branch responsible for the action. However, the moderator still should not be directly responsible for the action, in order to assure the appearance of objectivity. Where such a moderator conducts himself in an objective fashion, he can be extremely 
successful because of his knowledge and importance in the overall DOE decision making process. In addition, the presence of a high ranking DOE official as moderator enhances the degree of meeting importance to the agency. However, if the moderator becomes riled during a contentious meeting, he can significantly decrease the possibility that the designated meeting functions will be realized.

\section{Panel}

\section{Relevant Function}

The panel can assist in the realization of the following objectives: Legitimatacy, public acceptance and obtaining information. A panel present at a meeting can serve to legitimate the subsequent governmental action. When the panel successfully engages in a dialogue with those in attendance, it can increase the public acceptance of any governmental action. By carefully questioning the participants, it can increase breadth and detail of information collected during the meeting as well.

The composition of a panel is dependent on the objective of the meeting. Where the objective of the meeting is to relay information to the public, the panel should be composed of individuals intimately associated with and responsible for decisions relating to the 
governmental action. Where the objective is to obtain public input on a particular governmental action, it is also beneficial to have individuals associated with the project on the panel. In this case, however, it is also important to include independent individuals in order to maintain objectivity and to ensure that an accurate and broad perspective is reflected in the panel's report on the issues raised at the meeting.

The scale of the meeting can also influence the composition of the paneI and subject matter. Where the meeting is to review a generic policy or to discuss a particularly controversial governmental action, it is useful to have the panel primarily composed of independent individuals with significant knowledge of the general subject. Such individuals can provide DOE officials with the clearest sumnary and comments on the public meeting. Where DOE documents are central to the scope and subject matter of the meeting, the authors of the documents should be present, preferably with the major author included on the panel.

It is important that panel members understand the limits of public participation. For instance, the primary objective of the Uranium Mine Tailings Radiation Act is to minimize regional health concerns. Satisfaction of this objective may require locating the mill tailings in an area that did not generate or originally hold them. No one 
likes another's garbage and the siting of these tailings will always be a potentially contentious process. Consequently, while adequate public participation can minimize opposition, it will not generally prevent it. This realization by the panel members will allow them to proceed with and benefit from the testimony at the public meeting, and not be discouraged by the opposition that is still raised at the meeting.

6. DOE Personnel Attending the Meeting

Relevant Functions

DOE personnel in attendance at the meeting serve to legitimate the subsequent governmental action and if they successfully interact with the participants, they can also contribute to the public acceptance generated by the meeting.

While it is not always advisable to have DOE personnel on the panel or to act as the moderator, the DOE individuals who influence decisions concerning the subject of the meeting should attend the meeting. The presence of such DOE personnel at the meeting increases the legitimacy of any government decision resulting from the meeting and visibly conveys to the participants the importance of public participation in the DOE decision making process. It also ensures that the relevant DOE personnel will be 
able to acquire a firsthand understanding of the nature of the public's concerns.

7. Record of Testimony

Relevant Functions

The preparation of a record serves to increase the legitimacy of any action that may take place after the public meeting.

The testimony at a meeting should be transcribed, preferrably by a certified reporter visible to the public. A back-up tape recorder should be available and also visible. If a court reporter is not possible, a main and back-up tape recorder should be employed.

\section{Post-Meeting Elements}

1. Summary of recorded testimony. Relevant Functions

A summary of recorded testimony assists in the provision of information. Where the testimony was largely favorable to the DOE's proposed action, it can also serve to increase public acceptance.

Generally, the DOE should summarize the recorded testimony and make it available to the decision makers, as well as to the participants and public at large. Rapport 
with the participants can generally be increased if the DOE also provides written responses to the major issues raised in testimony.

2. Written testimony submitted after the meeting. Relevant Functions

Written testimony submitted after the meeting can enhance DOE's effort to obtain information or to legitimate its ultimate decision by allowing additional public comment.

Where it is the impression of the panel members that the perspective of the particpants may have been modified as a result of the meeting, it may be useful to request written comments submitted at some date after the meeting. There should be a page limitation on such material, in order to ensure that it is concise and confined to an actual response to the meetings. The resources of the various participants to provide such written comments should be considered prior to making a request for written comments subsequent to the meeting.

3. Post-Meeting Workshops

Relevant Functions

Post-meeting workshops can increase the guantity and quality of obtained information by DOE and serve to foster the public's acceptance of the ultimate action. 
In some instances DOE might find it advantageous to continue a dialogue in the form of a workshop between certain participants and DOE decision makers. It should be cautioned, however, that DOE might engender bad will among participants not invited to attend the subsequent workshops. 


\section{Appendix 1: \\ Guidelines for Determination of Need for Public Meetings}

The guidelines or standards applicable to determine whether to hold a public meeting are neither extensive nor particularly informative. The few that exist follow:

I. Department of Energy Citizen Participation Manual, DOE order 1210.1:

Policy Development. "There are no requirements for public participation in policy development. However, it is DOE policy to seek public participation to the extent.allowable on pending policy issues which are substantial and which have major impacts on the public." Sections I(3)b, DOE-C.P.P.M.

- The manual sets forth the following evaluation of public meetings.

Characteristics: Large meeting, less formal than the public hearing. Considerably more flexibility in meeting formats. Participants not asked to take definitive positions; may be some "give-and-take." 
Appropriateness: Might be used prior to public hearings (or independentlyt to present information and/or permit participants to discuss issues. Might be held in several regions to obtain greater participation.

Advantages: Can reach a large number of people at a single time. Can be held at any time in a process when information is to be presented and/or citizen comments are needed. Less intimidating than a public hearing.

Disadvantages: Unless the meeting subject is highly important to the public, attendance may be scarce. Limited opportunity for interaction among participants because of size. May be dominated by vocal minorities.

II. NEPA: Public Participation Requirements

The following DOE radioactive waste management activities should comply with NEPA requirements. Accordingly, these activities must follow the public participation criteria included in the NEPA guidelines. 
WASTE PROGRAM

High level waste

Spent nuclear fuel

Transuranic waste

Geological repositories

Low level waste

Inactive uranium mill tailings

Active uranium mill tailings

Formerly utilized sites

Decontamination and decomissioning of surplus facilities
ACTIVITIES SUBJECT TO NEPA REQUIREMENTS

- Tank storage

- Disposal program alternatives

- Project specific EIs's

- This program is under significant redefinition by the DOE at this time. Consequently, a review of public participation needs will not be relevant until the new program is defined further.

- TRU disposal alternatives

- TRU processing plant site selection

- National site characterization and selection plant

- Identification of specific siting locations

- Identification and banking of preferred sites

- Site selection

- Select appropriate remedial actions

- Select disposal sites

- Select remedial action

- Select remedial action disposal site

- Evaluate each D\&D disposition project

The NEPA regulations promulgated by the CEQ were adopted by the Department of Energy on July 30, 1969 in 10 CFR 1021. The pertinent section on public meetings follow. 
[The Sponsor Agency shall] "hold or sponsor public hearings or public meetings whenever appropriate or in accordance with statutory requirements applicable to the agency. Criteria shall include whether there is:

(1) Substantial environmental controversey concerning the proposed action or substantial interest in holding the hearing.

(2) A request for a hearing by another agency with jurisdiction over the action supported by reasons why the hearing will be helpful. If a draft environmental impact statement is to be considered at a public hearing the agency should make the statement available to the public at least 15 days in advance (unless the purpose of the hearing is to provide information for the draft impact statement). 40 CFR Part 506.6 (C).

\section{Conclusion}

It is the practice of the DOE to encourage public participation in its policy making efforts. Moreover, within its definition of public participation, the waste management plan obviously includes meetings where all sectors of the public are invited and spirited exchange is expected. While the plan is vague concerning when a meeting should be scheduled on either 
individual programs or the plan generally, the above requirements/guidelines can be consolidated into the following criteria.

\section{Non-NEPA Activities:}

Where it is a non-NEPA activity that is under review, the public should be involved where any of the participation objectives stated in the plan could be realized--specifically: information dissemination, information collection, or feedback. In order to determine the form of public participation, the advantages and disadvantages of public meetings, as stated in the plan, should be evaluated. If the advantages are greater than the disadvantages, especially in comparison to a similar:assessment of the other forms of public participation, public meetings should be the suggested way to go forward. (The DOE public participation plan has a similar review of the characteristics, appropriateness, advantages and disadvantages of the other recognized forms of public participation.)

\section{NEPA Activities}

Where the form of public participation is under consideration for one of the specific NEPA activities defined in the plan, the NEPA decision criteria for public meeting should be applied. That is, whether the issue generates substantial controversy, whether there is a request for a hearing from another agency with jurisdiction over 
the action, or whether a meeting is necessary in order to solicit needed information from the public. Of course, in this instance the public meeting criteria set forth in the plan can and probably should be applied as well.

Where it is arguable that some form of the NEPA process should be followed, even though it might not be specifically required in this present draft of the plan, the issue of whether to hold a public meeting could also be considered utilizing the NEPA criteria. 


\author{
Appendix 2 \\ ORGANIZATION, PURPOSE, AND \\ FORMAT OF PAST NUCLEAR WASTE MEETINGS
}

This appendix summarizes some of the significant aspects of past nuclear waste meetings. It is based on published reports and, when available, notes of participants.

\title{
(1) Mitre/Interagency Public Policy Conference
}

This meeting was organized by: (1) a government interagency steering committee, (2) the Mitre corporation, and (3) an external planning and advisory group, from which Mitre solicited input at the steering committee's suggestion. The external planning and advisory group included representatives from environmentalists, special interest groups, congressional staff, state government, industry, media, and others. Thus, an attempt was made to give important participants a role in planning the meeting.

The purpose of the meeting was to provide a public for um to identify and discuss legal, institutional, social, environmental, and other policy issues relating to nuclear waste management. Excluded from the purpose was a debate about the acceptability of nuclear energy. Rather, the meeting was intended to encourage an exchange of information and viewpoints about establishing a national waste policy. 
The format of the meeting was similar to an academic conference. Various sections were organized, and someone delivered opening remarks. These opening remarks were followed by formal papers, panel discussions or overview statements, and question-and-answer periods.

As a means of emphasizing areas of agreement, summaries of each session were presented at the conference's completion. For example, conferees agreed that "the problem of implementing waste management goals involves major social, ethical, and moral issues, which it is difficult to separate completely from technical issues; and this is primarily because of the problem of drawing inferences from uncertainty."

Citizen group representatives from environmental organizations were dissatisfied with the results of the meeting. Environmentalists complained that it was held during the middle of week when only paid professional staff could attend, that it was held in a single location which required considerable travel, and that it underrepresented people opposed to nuclear energy.

\section{(2) EPA Criteria Workshop}

Participants at the 1977 EPA Criteria Workshop received a document "Issues and objectives statements" that provided background on three topics that were discussed at the meeting: (1) policy and technical considerations for high level radioactive waste; (2) policy and technical considerations for 
low level and intermediate level radioactive waste; and

(3) public acceptability of risk from radioactive waste. This meeting also was conducted very much like an academic conference with opening remarks, formal presentations, and question-and-answer sessions. Most of the first day consisted of planned sessions during which invited participants presented papers on the issues. However, the second part of this meeting was devoted to small working group sessions, each of which addressed one of the topics of the workshop. Each working group was moderated by a member of EPA's legal staff, and several EPA technical staff members were present. Following its discussions, each working group convened an executive session to prepare a summary report including all consensus views as well as individual expressions of opinion on major items of discussion.

The summaries and conclusions, which had to be approved by the full working group prior to the final plenary session, were included in published proceedings. The EPA conference thus ended in consensus about a variety of issues:

(1) General agreement that criteria EPA develops should apply to waste management and not address disposal alone.

(2) ' Consensus that all unplanned events and actions should be considered by EPA in developing criteria and setting standards. 
(3) Agreement that retrievability should be considered only when safety would not be compromised.

(4)- General agreement about how to calculate maximum individual and population dose limitations.

This is only a sample of the many items of agreement. Absolute consensus was not reached on these issues. Still, the summary papers revealed enough agreement on the major factors underlying continuing controversies so that EPA would have some guidance when making decisions.

\section{(3) EPA's Criteria Forum}

EPA used the same format as in the earlier meeting: issue papers and formal presentations about specific topics beforehand, and then working group sessions which had to produce statements of agreement. The topics considered by this meeting were: (1) what is radioactive waste?. (2) what are the characteristics of an adequate risk assessment, and what are acceptable risks from radioactive waste? and (3) what control measures should be undertaken for radioactive waste? Topical presentations by EPA staff addressed these issues. Participants then divided into working groups on the basis of topic areas. They were restricted in subject matter. They could not consider subjects not under EPA's jursidiction, even if they pertained to 
criteria for radioactive waste. Summary reports of the working groups were prepared by group volunteers, subject to group approval. Not without contending views, the forum like the earlier workshop ended in substantial agreement about a variety of key issues.

\section{(4) DOE WIPP Meetings}

The subject matter was the building of a waste isolation pilot plant in Carlsbad, New Mexico. The meetings were held in the areas where the affected citizens resided, in Carlsbad and Alburquerque. The format of the DOE/WIPP meetings was: first, formal presentations by DOE and other government officials; followed by, prepared statements by citizens; and finally, a question and answer period. Forms were distributed for written public comments from those unable or unwilling to speak.

Specific rules governed the question and answer session. Those asking could ask only one question, with one follow-up question only. Further questions could be posed, only after other citizens had an opportunity to speak. The purpose of these rules was to allow "maximum participation." One observer describes the question-and-answer period in the following terms:

The question period was somewhat more lively and hostile (in comparison with the formal presentations). People asking questions were baiting the main speakers on the podium. There was a good deal of audience reaction in an environment much like a home 
court basketball game. Deutsch kept his cool and gave detailed technical and lengthy answers. Clarification questions went on an hour and fifteen minutes longer than scheduled and had to be ended by a vote of the audience in order to proceed with the conference agenda.

The open-ended question-and-answer period, after the DOE and citizen statements, was lively and hostile. Time was insufficient for issues to be resolved, and agreement was not forthcoming.

\section{(5) IRG Public Review}

Chaired by John M. Deutsch from the Department of Energy, the Interagency Review Group was composed of representatives from fourteen government entities*. The purpose of the IRG hearings was to review a draft report of a document on nuclear waste policy that had been prepared for submission to the President. Fifteen thousand copies of the draft were issued for review and comment, which led to a very large volume of correspondence and comments on its contents. The draft report dealt with decision making processes, the technical strategies,

₹ The Department of Energy, the Department of state, the Department of Interior, the Department of Transportation, the Department of Commerce, the National Aeronautics and Space Administration, the Arms Control and Disarmament Agency, the Environmental Protection Agency, the office of Management and Budget, the Council on Environmental Quality, the office of Science and Technology Policy, the office of Domestic Affairs and Policy, the National Security Council, and the Nuclear Regulatory Commission. 
institutional issues, and management considerations of waste disposal. Issues such as cooperation between state and Iocal governments, waste management costs and financing, risk assessment, and regional site selection were discussed in the draft report.

The IRG analysis of public comments notes the following:

1. Many citizens from the public at large felt that the "process was a charade in view of the short time frame for comment";

2. Many of the comments went beyond the specific issues, as fifty-three percent of the speakers "used the meeting to speak on issues such as pro- and anti-nuclear sentiment, alternative energy sources, or the public participation process."

3. The sentiments were "basically anti-nuclear:" $21 \%$ requested a moratorium on waste generation and weapons production; 25 requested a cessation of all future nuclear developments; 298 questioned the credibility on the whole nuclear waste issue; and only 148 agreed with the IRG findings .

Table 1 analyzes concerns of the participants based on IRG's content analysis. Clearly, nontechnical issues such as federal involvement and anti-nuclear comments dominated 
Table 1: Concerns of EIS Participants*

NON - TECHNICAL

Policy Issues and General Comments

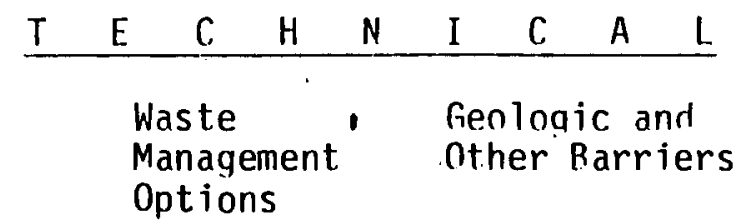

Cons equence Analysis
Alternative

nisposal

Concepts

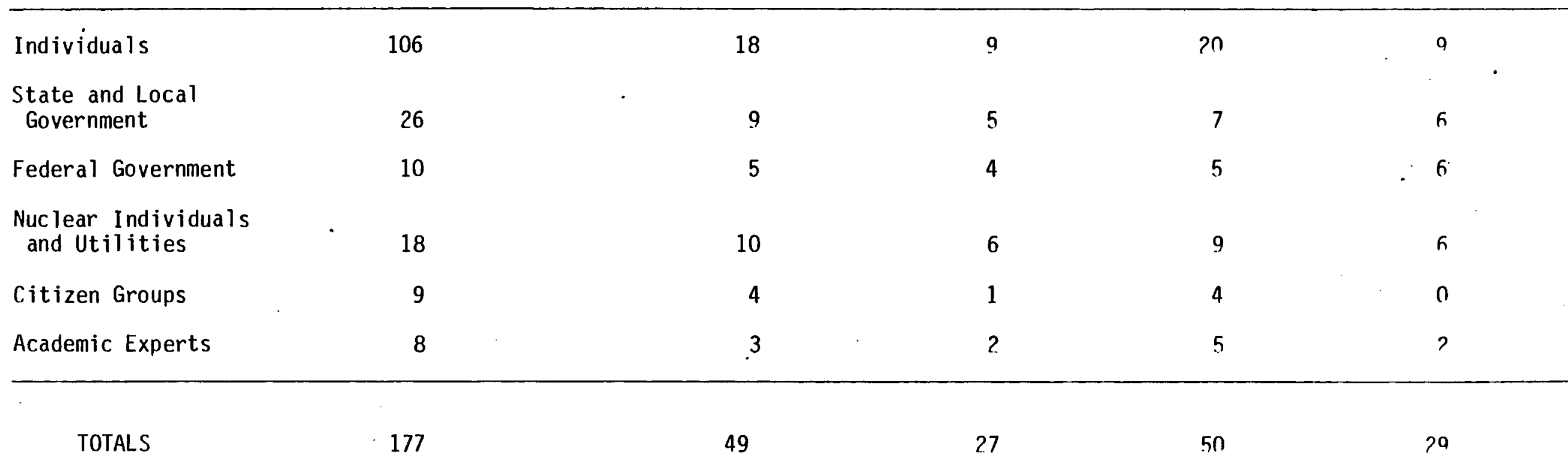

*Developed from DOE content analys is

P15465

$4148 X$ 
participant concerns. Anti-nuclear comments by all groups, except the nuclear industry, outnumbered pro-nuclear comments.

In its response to the critics of nuclear power, the IRG made two points. First, it emphasized its "neutrality" in regard to the future of nuclear power and its relation to other energy sources:

The future of nuclear power and the relation of this energy source to other energy sources are important questions that will be debated in many forums, but the IRG believes it should not participate in those debates. The IRG reiterates its views that its standards, criteria, and regulations to protect the public must be developed neutrally.

Second, the IRG admitted to a split in its ranks. Some of the members apparently did not believe that the report adequately met "its own stated criteria for neutrality." The ways in which differences in future nuclear growth might heighten or reduce waste management difficulties were not sufficiently addressed by the report, according to the dissenting members.

The IRG concludes that "all three meetings experienced periods of public tenseness, displeasure, and hostility toward the federal panel assembled." But, it also goes on to argue that all three sessions "developed into candid, respectful dialogues ."

(6) Congressional WIPP Hearings

Convened by a Subcommittee on Oversight and Investigations of the House Committee on Interior and Insular Affairs, the WIPP 
(waste isolation pilot plant) hearings also took place in Carlsbad and Albuquerque, New Mexico. Again, the issue discussed was the withdrawal of land from public use for the purpose of establishing a nuclear waste isolation pilot plant. The WIPP procedures involved formal testimony in which witnesses were invited to offer their views about specific areas of interest. Witnesses received letters from Congress inviting testimony and had five to ten minutes to give a summary presentation. (In addition, they had the right to submit written documents.) After their presentations, witnesses were questioned by the Congressmen. A summary of the positions of six groups of participants (state and local officials, citizen groups, federal government officials, nuclear industry and utilities, other economic interests, and academic experts) is presented below. The summary shows that no clear consensus about issues emerged at this meeting.

State and local officials. State and local officials who participated included a mayor, a county commissioner, state civil servants, and others. The mayor was interested in socioeconimic impacts, the opposition of people who lived close to the sites, and the retrievability of the waste. The county commissioner, unlike the mayor, argued very strongly in favor of the pilot project. The director of the state's environmental evaluation group, on the other hand, expressed concern about uncertainties, assumptions, and the interpretation of data about potential releases of radioactivity. 
Citizen groups. Three citizen groups participated; two were opposed to the project and one endorsed it. The opponents discussed the "cancers" and "deaths" that could result from contamination. They questioned DOE's decision making processes and its technical capabilities, and they charged that DOE had suppressed information. They made the point that the state had committed itself to the project, but the "people did not favor" it and cited surveys and polls that showed citizen opposition. They also complained that the hearings had been poorly advertised and were held during times of the week when ordinary people had to work. The proponents of the project, on the other hand, spoke of the need for the country to survive as a strong and viable entity and to prosper and they discussed the important role that nuclear power had in accomplishing these goals.

Federal government officials. Federal government officials included a U.S. Senator, officials from the DOE, and officials from the DOI. The Senator argued for federal partnership with the states. DOE officials expressed their willingness to carry out congressional mandate, while DOI officials clarified legal procedures for withdrawing land from public use.

Nuclear industry and utilities. Nuclear industry and utility officials discussed socioeconomic impacts of the project--increased employment, added dollars to the local economy, larger population, greater demand for public and private services and so on. They emphasized the importance of 
the project to the local economy and the adequacy of the technology and tried to assure people that there would be no harmful exposure to human populations.

Other economic interests. These interests argued that the project site had considerable hydrocarbon and mineral potential, and that these lands should not be withdrawn from use.

Experts. The experts disagreed. An official from the U.S. Geological Survey stated that "on purely technical grounds, no particular geological environment is the obvious preferred choice at this time;" while the manager of nuclear waste from Sandia noted that technical analysis, engineering analysis, and other types of analysis were nearly complete and showed that the proposed site adequately met site selection factors. Officials from the U.S. Nuclear Regulatory Commission clarified licensing procedures and noted that the "go-ahead" decision could be held off until other sites were characterized.

\section{(7) DOE Environmental Impact Hearings}

Convened by the Department of Energy's Office of Nuclear Waste Management, the GEIS Hearings were held in five cities between June and October of 1979. The purpose was to comment on a draft DOE environmental impact statement that had been issued on April of 1979 and to identify key issues to be addressed during preparation of the final document. A Hearing Board, chaired by a lawyer and consisting of professors of sociology, 
environmental engineering, geochemistry, and nuclear engineering presided. To attract participants, notice was made in the Federal Registrar, and advertising was carried out in local newspapers and on local radio and television stations.

Table 2, developed from a DOE content analysis, presents issues that were of concern to participants. The table shows that policy issues and general comments of a nontechnical nature were of significant concern to all groups including the nuclear industry. Technical matters such as geological and other barriers, consequence analysis, alternative disposal concepts, and waste management operations in total received slightly less mention.

Among the participants, the ratio between nontechnical and technical comments was highest for individuals. As can be seen in Table 3, individuals, state and local governments and citizen's groups had a ratio of non-technical to technical comments of 1.0 or more, while the federal government, nuclear industry and utilities, and academic experts had a ratio below 1.0 .

DOE held that the policy issues raised were predominantly "subjective" in nature: "in most cases, policy issues did not directly address the draft statement." DOE's content analysis of policy issues shows that the most common policy comments called for the slowing down or halting of the generation of electricity by nuclear power or ordered a stop in the production of more nuclear waste. Sixty-three participants made this 
Table 2: Concerns of IRG Participants*

$\begin{array}{lllll}\text { Federal } & \text { Anti-Nuclear } & \text { Alternative } & \text { Pro-Nuclear } & \text { Spent } \\ \text { Involvement } & \text { Comments } & \text { Technology } & \text { Comments } & \text { Fuel }\end{array}$

rategies

43

36

19

16

11

8

12

7

1

1

1

4

3
TOTALS

163

159

140

53

42

39

*Based on IRG content analysis, IRG, 1979. 
comment. Other policy issues and the number of participants that addressed various concerns are listed below:

Opposed to siting repositories in a given area or in a particular place (33)

Proceed with a demonstration (25)

Develop other methods of generating electricity (23)

Eliminate waste management alternatives because of cost, safety, or technology (20)

Move more deliberately or cautiously (16)

Make utilities that are generating waste responsible for waste disposal (16)

The following is a summary of some of the technical issues discussed at the meetings:

Geological considerations and other barriers to disposal. Among the issues discussed were alternative geological media; the difficulty of relying on laboratory measurements; deformations; erosions, and volcanic activity; the resource potential of the host rock; possible changes in climate; and other uncertainties about projected behavior of the system. 
Table 3: Ratio Between Nontechnical and Technical

$$
\begin{gathered}
\text { Issues Among Participants } \\
\text { At GEIS Hearings }
\end{gathered}
$$

\footnotetext{
Nontechnical (NT) = Policy Issues and General Comments

Technical $(T)=$ Geologic and Other Technical or Natural Barriers, Consequence Analysis, Alternative Disposal Concepts and Waste Management Operations
}
$\underline{N T / T}$
INDIVIDUALS
1.9
STATE AND LOCAL GOVERNMENTS
1.0
FEDERAL GOVERNMENT
.5
NUCLEAR INDUSTRY AND UTILITIES
.6
CITIZEN GROUPS
1.0
ACADEMIC EXPERTS 
Consequence analysis. Dose calculations, radiological issues, and the uncertainties of risk analysis were discussed. The exact nature of the radiation dosage to individuals and the plausibility of existing calculations were questioned. Assumptions and computer models, accident scenarios, and accident potentials were also explored.

Alternative disposal concepts. The following alternatives were discussed: very deep holes; rock melting; island disposal; subseabeds; ice sheets; reverse well; and space disposal. Containment, leakage considerations, permeability, and thermal mechanical behavior were also discussed.

Waste management operations. The issues were numerous: assumptions regarding nuclear power plant performance; information on nuclear growth $\bar{i}$ schedules for transporting waste from power plants to disposal facilities; definitions of waste and its characteristics; packaging of spent fuel; use of concrete in storage and separation; other aspects of storage facility design including useful life; interim storage; water basin storage; decommissioning; repository construction (rooms, shafts, tunnels); costs; and fuel cycles.

In responding to the comments, DOE made no response to the attacks on nuclear power generally. Most of its comments focused on the technical issues. 


\section{$\underline{\text { References }}$}

Burke. Citizen participation strategies. Journal of the American Institute of Planners, 1968, 34, 287-294.

Fox and wible. Information generation and communication to establish environmental quality objectives. Natural Resources Journal, 1973, 13, 134-149.

Gamson, w. Power and discontent, 1968.

Iindzey, G., and Aronson, E. (Eds.), The handbook of social psychology, 2nd Edition, Volume 3 , The individual in a social context. Menlo Park, California: Addison-Wesley Publishing Company, 1969.

Loye, D. The knowable future: A psychology of forecasting and prophecy, 1978 .

Reidel. Citizen participation: Myths and realities. Public Administration Review, 1972, 32, 211-219.

Schattschneider, E. E. The semisovereign people, 1960.

Selznick, P. TVA and the grassroots, 1963.

Wald, H. P. Reflections on administrative hearings. Public Utilities Fortnightly, 1978, 10l, 21-25.

White, G. Formation and role of public attitudes. In $\mathrm{H}$. Jarret (Ed.), Environmental quality in a growing economy, 1966.

White, G. The role of public opinion. In McGoldman (Ed.), Environmental quality and water development, 1973.

Willeke, G.E. Theory and practice of public participation. Journal of the Irrigation and Drainage Division,

Proceedings ASCE, 1974, 100, 75-86. 
No. of

Copies

E. E. Anschutz, Director

DOE External Nuclear Affairs

Washington, D.C. 20585

W. Ballard, Jr.

DOE Office of Energy Programs

Washington, D.C. 20545

D. L. Bedde

Congressional Budget Office

Room 410-HA\#2

2nd \& D Streets, S.W.

Washington, D.C. 20515

A. A. Churm

DOE Chicago Patent Group

9880 South Cass Avenue

Argonne, IL 60439

W. K. Davis, Deputy Secretary

DOE

Washington, D.C. 20585

27 DOE Technical Information Center P.0. Box 62

Oak Ridge, TN 37830

C. H. George

DOE Office of Waste Isolation

Washington, D.C. 20545

G. Graves

Los Alamos Scientific Laboratory

Los Alamos, NM 87544

J. P. Hamric

DOE Idaho Operations Office

550 Second Street

Idaho Falls, ID 83401

C. A. Heath

NUS

910 Clopper Road

Gaithersburg, MO 20878

D. Jackson

DOE Office of Public Affairs

Albuquerque Operations Office

Albuquerque, NM 87115
No. of

Copies

J. Jackson

Argonne National Laboratory

Argonne, IL 60439

R. Jefferson

Transportation Technology Center Sandia National Laboratories

A]buquerque, NM 87102

E. A. Jordan

DOE Office of Waste Isolation

Washington, D.C. 20545

R. Laskiewicz

Argonne National Laboratory

Argonne, IL 60439

M. J. Lawrence

DOE Office of Transportation and Fuel Storage

Washington, D.C. 20545

R. L. Lowrey

Albuquerque Operations Office

Albuquerque, NM 87115

J. B. Martin

NRC Division of Fuel Cycle and Material Safety

Washington, D.C. 20555

E. F. Mastal

DOE Office of Resource Management and Planning

Washington, D.C. 20545

D. F. Miller

DOE Office of Public Affairs

Nevada Operations Office

Las Vegas, NV 89114

A. H. Morgan, Director DOE Office of Public Affairs Washington, D.C. 20585

R. L. Murray

Nuclear Engineering Department North Carolina State University Raleigh, NC 27650 
No. of

Copies

J. 0. Neff

DOE National Waste Terminal

Storage Program Office

Columbus, $\mathrm{OH} 43201$

G. K. Oertel

DOE Office of Waste Operations and Technology

Washington, D.C. 20545

A. F. Perge

DOE Office of the Deputy Assistant Secretary for Nuclear Waste Management Washington, D.C. 20545

R. Pierre

Argonne National Laboratory

Argonne, IL 60439

J. Pomeroy

National Academy of Sciences

Washington, D.C. 20518

R. W. Ramsey, Jr.

DOE Projects Staff

Washington, D.C. 20545

G. K. Shriver

DOE Office of Public Affairs

Washington, D.C. 20585

L. J. Smith

TRU Waste Systems Office

Rockey Flats Plant

Golden, CO 80401

J. P. Thereault, Director

DOE Plans and Evaluation Staff

Washington, D.C. 20585

S. L. Topp

Savannah River Laboratory

Aiken, SC 29801

V. G. Trice

DOE Office of Resource

Management and Planning

Washington, D.C. 20545
No. of

Copies

E. J. Wahlquist

DOE Office of Resource

Management and Planning

Washington, D.C. 20545

Office of Nuclear Waste Isolation
N. E. Carter
J. Finley
M. Kehnemuyi
D. L. Keller
J. M. Mountain
B. A. Rawles

Richland Operations Office

3 - Sontract Office

T. A. Bauman

P. A. Craig

R. B. Goranson

R. W. Newl in

H. E. Ransom

J. J. Schreiber

M. W. Shupe

F. R. Standerfer

Pacific Northwest Laboratory

5 Technical Files

2 Publishing Coordination

J. B. Burnham

T. D. Chikalla

D. E. Deonigi

M. R. Kreiter

J. M. Latkovich

R. C. Liikala

R. P. Marshall

D. E. Olesen

A. M. Platt

5 J. V. Robinson 